\title{
AGRICULTURA E INDÚSTRIA: O CASO DO TOMATE EM TAQUARITINGA, S.P.
}

\author{
fRAncISCO GRAZIAno neto
}

Orientador: RODOLFO HOFFMANN

Dissertação apresentada à Escola Superior de Agricultura "Luiz de Queiroz", da Universidade de São Paulo, para obtenção do título de Mestre em Economia Agrária.

PIRACICABA

Estado de São Paulo-Brasil

Outubro 1977 
I Tais, esposa e companheira

DEDICO

$\bar{A}$

Andrē e Daniel, meus filhos

OFEREC $O$ 
A G R A D E C I M E N T O S

Em eapecial, agradeço po Prof. Dr. Rodolfo Hoffmann, orientador desta Dissertaça e sincero amigo que, pelo seu bri hantismo intelectural, deu apoio decisivo para a realização deste trabalho, principalmente em sua etapa final;

aos colegas do Departamento de Economia Rural da Faculdade de Ciências Agrärias e Veterinārias de Jaboticabal UNESP, particularmente a José J. Gebara, Silvio P. Zamboni, e Argemiro 0 . Sousa, pelas constantes críticas e sugestões no decorrer do trabalho;

a Oriowaldo Queda, Ãngela A. Kageyama, Marilda Yamamoto e, em particular, a Flávio A. Pinheiro, pela atenciosa leitura dos manuscritos;

a Geraldo S. de Barros e Fernando C. Perez, pelas criticas apresentadas na "mini-banca";

a Geraldo Geraldi e Schinechi Kamada, Eng:-Agro Regionais de Taquaritinga e Monte Alto, respectivamente, pelo au xílio na coleta de dados;

a otávio s. Gutierrez, grande amigo, que, com seu es pírito crítico, em muito contribuiu para o desenvolvimento des te trabalho;

a D. Ercy H. de Oliveira e Aparecido L. Cremonez pelos valiosos serviços de datilografia, em rascunho; 
à Fundeçäo Ford que, através de convênio com o Depax tamento de Ciências Sociais Aplicadas da Escola Superior de Agricultura "Luiz de Queiroz" - USP, forneceu os recursos para a publicação desta Dissertação;

$$
\text { Resta acrescentar, como è praxe, que os acima mencio }
$$
nados nada têm a ver com os deméritos dessa Dissertação. Esses cabem exclusivamente ao autor que, com sua mania de inde pendência intelectural e de não sujeição a linhas de pensamento pré-estabelecidas, acaba incorrendo em falhas como as que este trabalho possa encerrar. 
2 - O DESENVOLVIMENTO DO CAPITALISMO E A TRANSFORMAÇAO DA AGRICULTURA $\ldots \ldots \ldots \ldots \ldots \ldots \ldots \ldots \ldots \ldots, 17$

3 - 0 PROBLEMA TEర́RICO DA EXTRAÇAO DE EXCEDENTE

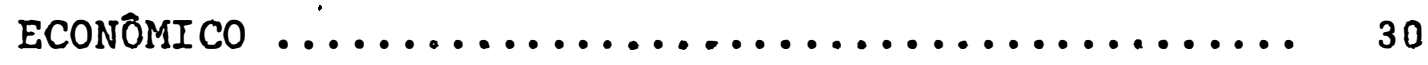

4 - TAQUARITINGA: CARACIERISTICAS GERAIS E EVOLUÇÃO AGRICOLA $\ldots \ldots \ldots \ldots \ldots \ldots \ldots \ldots \ldots \ldots \ldots . \quad 45$

5 - A EVOLUÇÃ DA AGROINDÚSTRIA NA REGIÃO $\ldots \ldots \ldots \ldots .66$

6 - A AGROIND

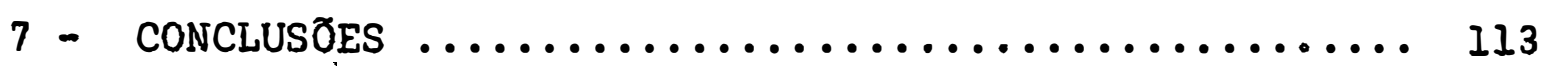

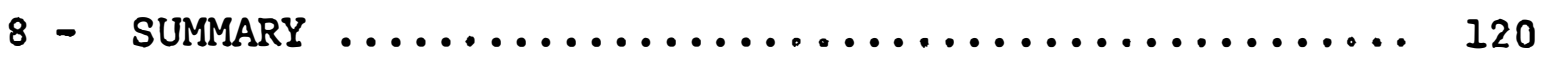

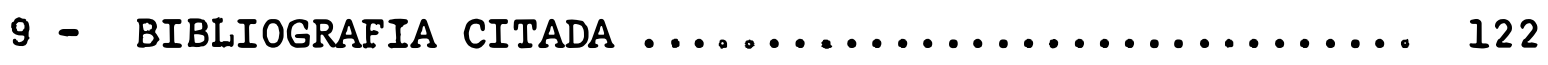




\section{INDICE DE TABELAS}

\section{TABELAS}

1 Area com café, percentagem da ärea total e número de trabalhadores ocupados - 1942 Principais municípios da região Noroeste SP.

2 Número e idade dos cafeeiros - 1942 - Principais municípios da região Noroeste, SP. ....

3 Produção de algodão em caroço - safra 1938/ 39 - Alguns dos principais municípios produ tores do Estado de São Paulo ...............

4 Evolução da quantidade colhida dos princi pais produtos agrícolas do município de Taquaritinga, SP.

5 Evolução da ārea plantada e do número de produtores para os principais produtos em Taqua ritinga, SP., 1959 e 1970

6 Indices de concentração da posse da terra em Taquaritinga e região, comparados à outros Iocais

7 Evolução da produção de tomate em são Pau lo e Pernambuco ........................

8 Resultado econômico da cultura de tomate, se gundo o sistema de plantio - SP. , safra de 
9. Produção e industrialização do tomate, São Paulo, 1968/75 (1.000 toneladas) ......... 72

10 Area colhida e produção de tomate no ano de 1955 - Vărios municípios - SP.

11 Proctuça de tomate, em toneladas, nos municípios de Monte Alto e Taquaritinga - Déca-

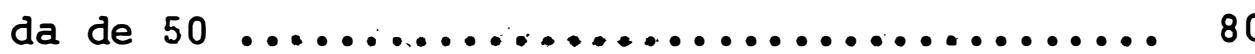

12 Evolução da produção de tomate no município de Taquaritinga, SP.

i3 Produção total de tomate na Microregião Ho mogênea 612 - Serra de Jaboticabal - 1972 .... 84

14 Produção de tomate em Taquaritinga, SP., por

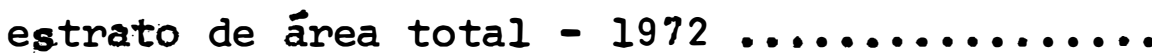

15 Utilização das terras em Taquaritinga, SP. 1950,1960 e 1970

16 Nümero de produtores e ārea plantada com tomate segundo a condịão do produtor. Taquari tinga, SP. 1976

17 Produção de tomate entre os proprietários por estrato de ārea total. Taquaritinga,

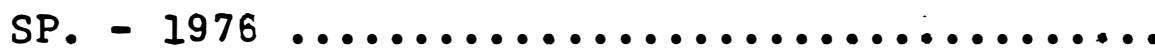


vii.

TABELAS

Pägina

18 Nümero de produtores de tomate por estrato de área com tomate. Taquaritinga, SP. 1976

19 Areas com outras culturas entre os proprietários produtores de tomate. Taquaritinga,

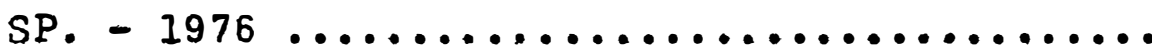

20 Origem da assistência tēcnica aos produtores de tomate - Taquaritinga, SP... 1976 ...... 


\section{RESUMD}

A preocupação fundamental deste trabalho é a anälise das relações entre o setor industrial e o agrícola no Brasil. Mais especificamente, estudamos as relações entre a indústria processadora de tomate e os produtores rurais de tal materriaprima na região de Taquaritinga, SP.

Na primeira parte do trabalho, fazemos algumas colocações sobre o desenvolvimento das relaçöes capitalistas de produção na agricultura num paIs periférico como o Brasil, e uma vez que o nosso objetivo é apreender como parte de um exce dente econômico gerado no âmbito da produção agrícola é transferido para o setor näo-agrícola da economia, mormente para as Indũstrias que se colocam a jusante da produção de matériasprimas, fazemos também uma discussão teörica sobre excedente e conômico e as formas de sua transferência para o setor indus - 
trial.

o suporte teórico no qual estamos embasados deriva da teorla marxista, em que se considera que excedente é trabalho năo-pago, ou trabalho excedente, cuja apropriação assume a forma de mais-valia numa sociedade capitalista.

Após um levantamento histórico da economia agrícola e do desenvolvimento da agroindüstria do tomate a nivel regional, entramos em malores detalhes na anălise dos vinculos existentes entre os produtores rurais e as fábricas processadoras, verificando que essa vinculação reflete uma relação de dominação=su bordinação entre os dols setores.

Percebemos que é ao nível das relaçōes de mercado que pelo menos parte do excedente agrícola é transferido para o polo industrial. Dado o fato deste ültimo constituir-se como um oligopsônio, enquanto a produção agrícola é pulverizada,a indug tria Impõe a sua razão sobre a agricultura. As possibilidades da usurpação efetuada sobre os produtores encontram um limite no ponto em que os mesmos desistam da produção agrícola, pois a indüstria ficaria tolhida do fornecimento da matéria-prima, jă que não a produz.

A conclusão geral a que se chega é que a agricultura, por ser um suporte da acumulação global do sistema económico, deixa de ter uma dinâmica própria, sendo, até certo ponto, mani pulada de acordo com as necessidades da reprodução do capital no setor industrial da economia. 


\section{1 - INTRODUCAO}

A preocupação inicial deste trabalho deriva de uma te mática mais geral que tem como centro de anälise apreender a ma neira pela qual a agricultura brasileira relaciona-se com o ton do da economia capitalista de nosso país, ou mais especificamen te, de como a agricultura contribui para a acumulação de capital do sistema produtivo instalado. Em ültima instância,pois, a preocupaçăo é com o desenvolvimento do sistema capitalista de produçăo no Brasil, especialmente sua realização na agricultu ra.

Vårios trabalhos, relativamente recentes, têm enfocado essa problemätica, mostrando-nos que o desenvolvimento do capitalismo no Brasil apresenta certas particularidades que con figuram uma situaçăo diferente daquela encontrada nos países de desenvolvimento capitalista originărio. 
Essas especificidades dizem respelto à sobrevivência ou manutenção de determinadas relaçães de produção, assim como formas de trabalho a elas associadas, que se configuram como capitalistas atipicas. De acordo com SILVA (1976a: 27), "E importantíssimo não desconhecê-las, isto ë, não desconhecer as suas especificidades, pols é atravẻs do seu estudo que podemos conhecer as especificidades das contradiçöes do capitalismo na agricultura brasileira, Indispensăvel ao conhecimento do capitalismo no Brasiln.

DUARTE e QUEDA (1974:92-92), discutindo a questão da agricultura de subsistência, afirmam que "E essa maneira pela qual o sistema repõe nas suas margens (internas, à beira da grande exploração, ou externas, na fronteira agrícolal formas de exploração não capitalistas, que precisa ser esclarecida. Mais do que isso: a reposição dessas formas liga-se ao processo de acumulaçāo (ou constitul um momento desse processo) no sistema global e pode configurar uma especificidade desse sistema".

0 ponto de partida para os estudos a que estamos referindo, Inclusive do que se esboça nessas linhas, diverge fun damentalmente do "approach" frequente, que tem enxergado a agricultura como entrave ao desenvolvimento nacional, principa mente pelo fato dela apresentar um setor tradicional, em oposi çăo ao setor moderno, que freila as possibilidades de sua expan são, conflitando com o desenvolvimento dos outros setores da economia. Essa linha de anålise leva portanto a afirmar a 
necessidade da modernizaçāo do setor tradicional, ou a necessidade de corrigir as deformaçóes do setor agricola, para que o mesmo tenha condiçōes de contribuir eficazmente pare o desenvol vimento económico do pais.

Por detrăs dessa análise estä a concepção de que a salda da situação de subdesenvolvimento nacional deve ser busca da na eliminação das deformaçōes existentes, principalmente na agrioultura. 0 processo de desenvolvimento é subentendido como a reprodução das fases ou etapas pelas quals passaram as eco nomias mals maduras, hoje desenvolvidas.

Rompendo com os esquemas funcionalistas e dualistas, têm-se procurado estudar as questões da agricultura brasileira dentro da ótica da acumulaçāo de capital, em que se enxerga o setor agrícola não como entrave ao desenvolvimento, mas como su porte importante para a acumulação de capital no setor industrial.

Esse rompimento significa, em ültima instäncia, reconhecer que o desenvolvimento histörico de qualquer sistema de produçāo, no caso, o capitalista, näo se dá linearmente, ou seja, não reproduz as mesmas fases pelas quals passou em outros paIses, fundamentalmente porque as condiçöes em que se processa a sua reprodução são diferentes.

SINGER (1973:68), analisando o processo de desenvolvimento capitalista dentro da economia brasileira, coloca que. em lugar algum, o sistema capitalista expandiu-se no văcuo, e que essa expansăo se dá às custas dos vărios modos de produçào 
prë-capitalistas que ainda subsistem nos paises nos quais ele se Impöe como dominante. No que toca ao Brasil "... o mesmo processo tende a se repet1r, mas com duas diferenças fundamentais: l) tendo-se iniciado muito mais tarde, o nosso processo de desenvolvimento é contemporêneo de economias capitalistas maduras, que nele intervêm pesadamente, dando-lhe características próprias, 2) dada a grande extensäo territorial do país, o excedente de população criado pela expansão capitalista (...) tende a reproduzir, no interior do pais, as formas prë-capitalistas que estão sendo aniquiladas nos centros mais dinâmicos da economia. Isto dá ao processo de desenvolvimento capitalista um carater recorrente * que ele não apresenta em outros lugares".

Isso nos leva a que o subdesenvolvimento, alëm de ser um processo histórico, è um produto, uma criação do próprio desenvolvimento. Näo só não há uma oposição entre os se tores chamados tradicionais qque confirguram a situação de sub desenvolvimentol e os modernos, como, pelo contrário, existe" ... uma simbiose e uma organicidade, uma unidade de contrários, em que o chamado 'moderno' cresce e se alimenta da existência do 'atrasado'" , nas palavras de OLIVEIRA (1974:9).

Diz LOUREIRO (1977:128) que "A partir dessa ötica,no vos problemas são colocados, tais como 'colonialismo interno'

(*) 0 grifo é nosso. 
entre Indústria e agricultura, reprodução de relaçōes não capitalistas, etc.. e antigas questões são redefinidas, como se pre tendeu fazer (...) com a parceria, isto $\Xi$, tratando-a como uma relação de produção não capitalista reproduzida pelo movimento de acumulação de capital e não como um arcalsmo que entrava o desenvolvimento capitalista".

Esse "colonialismo interno" entre setores de uma economia a que se refere LOUREIRO $\dot{B}$ a temätica geral deste estudo.

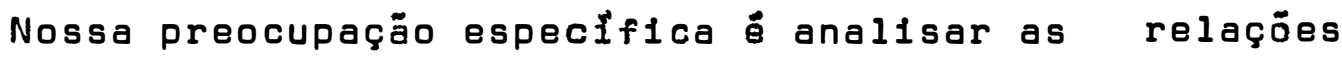
entre agricultura e Indủstria no Brasil, atentando para a deter minação dos vínculos que se estabelecem entre os dols setores, que permitem que o excedente eoonômico gerado seja apropriado pe10 capital industrial, favorecendo o processo de acumulação de capital no setor industrial.

Em outras palavras, objetiva-se analisar de que mane ra o excedente gerado no ámbito da produção agrícola transferese para o setor industrial. Escapam portanto de nossa preocupação específica as condições de acumulação, ou de realização desse excedente, em um setor ou outro. E claro que na medida em que haja essa transferêncla de excedente, as possibilidades de acumulação de capital na agricultura ficam prejudicadas, levando Inclusive a ameaçar a própria existência da acumulação de capital por parte dos produtores agrícolas. Entretanto, a verificação empírica dessa questão - feita necessariamente através do estudo da contabilidade agrícola - foge aos objetivos deste trabalino. 
Optamos pelo estudo de caso como mëtodo de investigaçăo científica por entendermos que tal metodologia de estudo é mais adequada, uma vez que, dados os objetivos a que nos propusemos, não tínhamos muita preocupação com a anälise quantitativa ou com a representatividade estatistica, mas sim com o aspec to qualitativo, em que o aprofundamento no problema em estudo era condição fundamental para a compreensāo do mesmo.

Näo se trata aqui de discutir em pormenores a metodologia escolhida. 0 caráter cientifico do procedimento se explicita, como coloca MARTINS (1973:40), "não pela generaliza ção empIrica e probabilistica, mas pela generalização que se al cança desvendando como o caso se configura a partir das media ções que estruturam a totalidade concreta, isto fenōmeno e o conhecimento para a sua concreticidade".

Na pesquisa empírica propriamente dita, analisamos as relações entre as fäbricas de processamento de tomate e os pro dutores rurais desse produto no municipio de Taquaritinga, Esta do de São Paulo. Alēm dos constantes contatos pessoais mantidos com os produtores rurais e com os representantes da indústria, necessários para adquirir-se uma maior vivência com o pro blema em estudo, recorreu-se ao levantamento de dados primä rios atravës de questionários. Apesar de objetivar-se entre vistar a totalidade dos produtores de tomate, foi possível fazê-lo com 56 dos mesmos. Posteriormente foram incluídos outros 15 produtores, dos quais se dispös somente de dados sobre área plantada com tomate e regime de posse, totalizando 71 produto- 
res, com quase certeza o nủmero total do municipio.

o caso do tomate nos parece um excelente exemplo para estudo. A instalação das fábricas processadoras incentivou sobremaneira o plantio do tomate no municipio, ao ponto de Taquaritinga ser conelderada a "Capital do Tomate", sendo, na ëpo ca do auge da cultura, o municipio de maior área plantada com tomate no mundo. Hoje, entretanto, a cultura do tomate restringe-se a uns poucos agricultores, e o volume da produçāo estä reduzido em quase $80 \%$, segundo dados do IEA (1976).

Nossa primeira preocupação era tentar determinar porque, num dado momento, as făbricas de processamento do tomate se instalaram no municipio.

Após a instalação da indústría e o consequente estímu 10 à produção do tomate, interessou-nos captar os vỉnculos que se estabeleciam entre a indústria e os produtores rurais, tendo como premissa que esses vinculos refletiam as relações de dominação-subordinação entre os setores, enxergados não como seto res "abstratos", mas sim vendo por detrás desses setores confli tos de classes que os representam. Por fim tratava-se de ex plicar o declínio da produçäo do tomate no município, relacio nando tal fenómeno com os pontos acima colocados.

Muitos foram os problemas enfrentados no desenrolar da pesquisa, e sua superação nem sempre fäcil e imediata. 0 primeiro deles, situado ao nivel mais material, diz respeito à coleta de dados secundários. Não tanto pela sua disponibilida de ou existência, mas principalmente pela confiabilidade dos da 
dos encontrados.

Sentimos bastante a dificuldade da realização de uma pesquisa efn que se necessite retroceder no tumpo. os dados disponIveis são desencontrados, tornando d1floil a comparậa quando dela se necessita. A superação dessas dificuldades e̊ conseguida na prätica da pesquisa, onde a conversa informal com determinadas pessoas aparece como elemento bastante importan te.

Dutro problema, esse situado a um nível mais abstra toj a portanto de mals dificil discussăo diz respelto à metodologla de pesquilsa, entendida aqui no sentido de como levar adiante um estudo que se tem em mente, a sua realização prática, o seu desenrolar.

E ponto pacifico que qualquer pesquisa se inicia no momento em que se definem os marcos conceituais ou o campo tẹ rico com que se pretende trabalhar.

A definição desse campo teörico exige o conhecịmento de uma certa referếricia bbibliogräfica, que dă a formação inte lectural geral do pesquisador. A escolha do "problema" a ser estudado não deixa de ser influencleda, e mesmo determinada. por essa formaçäo intelectual anterior e pelos valores que o cientista adquire na sua formação.

Por maior esforço que faça, é impossivel o pesquisador livrar-se da influência desses valores. GOLDMANN (1967: 19) , coloca assim a questäo: "O trabalho de pesquisa cientifica necessita liberdade e independência em fase de toda inge 
rência estrangeira. Do mesmo modo, exige do pesquisador, năo a renúncla de toda Ideologia, mas que faça todos os esforços de que é capaz para subordiná-la, no decorrer de seu trabalho, à realidade dos fatos estudados".

Não existe porém questão fechada quando se trata do modo como se relacionam ou se articulam a teorla e a pesquisa num caso concreto.

A pesquisa acadêmica formal tenta estabelecer fases. nesse relacionamento - a concepção verificacionista da ciên cia - donde, a partir da teoria, $\vec{e}$ deduzida uma hipötese, tendo a pesquisa como finalidade testar a hipötese elaborada e, consequentemente, a teorla que ihe serviu como ponto de parti da. Num esquema desse tipo, como coloca D'INCAO e MELO (1975: 18-19\}. "a teoria é o Infcio e o fim do processo cognoscitivo. o resultado é a elaboração de um conhecimento que não reflete a realidade, uma vez que esta passa a ser explicada através de princípios gerais e abstratos".

No processo do conhecimento cientifico é possivel per ceber-se dols procedimentos distintos, cuja diferença reside. em ültima Instância, no objetivo da pesquisa, no seu caráter, que pode ser diferenciado em dols niveis: o primelro, em que a pesquisa tem como objetivo o teste de uma teoria pré-estabele cida.

Nesse caso não hă, de um modo geral, qualquer preocupação que não seja a teorla, que ë o fim ültimo do estudo. Num esquema desse tipo, a realidade quase que somente tem serventia 
no sentido de um "locus" por onde perpassa a teoria em busca de comprovaçāo emplrica. Multas vezes ocorre uma inversāo da ordem das colsas: en vez de se adaptar a teoria à realidade, esta é que sofre adaptações para a teoria ser aplicada com sucesso. Como coloca PRADO JR. (1972:64): "... em vez de partir da anälise dos fatos a fim de derivar dal os conceitos com que se estruturarä a teoria, procede-se em sentido inverso, partindo da teorla e dos conceitos, que se buscam em textos consagrados a clåssicos, para em seguida procurar os fatos ajustávels em tais conceitos e teorias".

Q̣ segundo nível é aquele em que se busca, através de pesquisa, o entendimento de uma realidade concreta. o fim último do estudo não é uma teorla qualquer, mas sim. a percepção dos determinantes essenciais da realidade que se procura desven dar. 0 papel que a teoria exerce num estudo desse tipo,e ma1s que 1sso, a interrelação entre a teoria e a pesquisa propriamen te dita, é substancialmente diferente do caso anterior.

$$
\text { Nesse caso, como afirma D'INCAO a MELLO (1975:18), }
$$

"... a teoria passa a ter com a pesquisa propriamente dita uma relaçäo dialêtica. Ela projeta e antecipa a pesquisa ao mesmo tempo que reflete e registra seus resultados. Ela é, em sinte se, elemento de mediação na busca do conhecimento".

A teoria não é pois nem inicio nem fim do processo cognoscitivo. Este pressupõe um movimento de ida e vinda entre teorla e pesquisa, em que cada novo fato observado provoca uma volta ao conhecimento anterior, obrigando o seu questiona - 
mento e sua complementação, e a partir disso, uma nova volta à realidade. E somente dessa maneira que se atinge a essência dos fenômenos, que se compreende a realidade total.

Ao contrário do conhecimento sistemático, o pensamen to dialëtico parte do princlplo de que o conhecimento humano se processa num movimento recursivo, em espiral. Segundo KoSIC (1976:15), "A dialét1ca é o pensamento critico que se pró põe a compreender a 'colsa em si' e sistematicamente se pergun ta como é possivel chegar à compreensão da realidade". E ma1s adiante: "se a realidade é um todo dialético e estruturado, o conhecimento concreto da realidade näo consiste em um acrescen tamento sistemático de fatos, e de noções a outras noções. E um processo de concretização que procede do todo para as partes e das partes para o todo, dos fenōmenos para a esséncia e da essēncla para os fenómenos, da totalidade para as contradições e das contradiçōes para a totalidade, a justamente neste processo de correlações em espiral no qual todos os conceltos entram em movimento reciproco e se elucidam mutuamente, atinge a concreticidade" (pp 41-42).

Quando se procura compreender uma determinada real1dade, o processo de pesquisa é de diflcil esquematização, ao contrário da pesquisa que se pauta pelo teste de hipóteses pré viamente formuladas para verificação. 0 próprlo objeto de 1 n vest1gaçăo val sendo construído gradualmente, à medida que o trabalho se desenvolve. A lóglca causal contrapōe-se a "lög1 ca da descoberta". 
Ta1s colocaçöes podem causar espéc1e àqueles acostumados ao raciocinio lögico-formal. KAPLAN (1969:13) diz que "Nos seus plores momentos, o lóglco empolga-se tanto com realçar o poder e a beleza de seu instrumento, que perde de vista - materlal com o qual deve trabalhar. Nos seus melhores momentos, ele se prende a um discutivel platonismo: a maneira a dequada de analisar e compreender alguma colsa é referi-la a sua forma 1deal, ou seja, a uma forma abstrafda de qualquer en volvimento concreto. E um caminho, mas näo o únı́co, e achom me longe de estar convencido de que seja sempre o melhor".

A preocupação excessiva com "questäes de método" tem trazido prablemas no processo de conhecimento cientifico. E alnda KAPLAN (1969: 28) quem adverte: "Esforço excessivo pode ser desviado de problemas básicos para problemas metodológicos levando-nos a aperfelcoar continuamente a maneira de fazer alguma colsa, sem nos aproximarmos jamals de realizá-la sequer Imperfe1tamente".

Essa orientaçăo metodológ1ca dada à pesquisa é 1mpor tante que se diga, não fol determinada "a prior1". Aconteceu porĕm, que a prätica da pesquisa mostrou-nos a necessidade de romper com a esquematização inficlal, visto o caráter que assum1a o estudo. A medida que se aprofundava o contato com a problemática em questāo, lam aparecendo novos pontos não cons 1 derados Iniclalmente e que se mostravam importantes. Ultre passou-se em multo o esquema original que se mostrava insufi clente para o completo atendimento da realidade que se propu - 
nha desvendar.

E nesse sentido que colocamos a Impossibilidade do pré-estabelecimento do andamento de pesquisa. Parta-se ou não de uma hipótese, $\vec{e}$ somente o contato mals profundo com o problema que val estabelecendo os rumos que se deve seguir. Nesse procedimento, o corpo teórico inicial val sendo cont1. nuadamente complementado, repensado e ajustado à realídade que se está desvendando.

Näo se trata de negar o papel da teoria no desenro lar do trabaliho. Não resta dúvida de que o conhecimento teórico é de fundamental importância em qualquer pesquisa. 0 que se pretende é salientar a Importâncla prätica. Mals que 1sso. da relação dialética entre teoria e prätica numa pesquisa. Assim, ao mesmo tempo que se evita o espontaneismo, o teoricis mo também è descartado, surgindo a verdadeira cièncla, que năo admite verdades eternas e estätı́lcas.

Esse continuo movimento do conhecimento cientifico dă mostras de ser Interminável, e na verdade o $\hat{e}$, uma vez que a prōpria realidade concreta existe em continuo movimento;

Resta, nessa introduçăo, adiantar algo sobre o conteüdo do trabaliho.

o segundo capitulo da dissertação tratá em linhas ge rals da transformaçăo pela qual passa a agricultura com o desenvolvimento de sistema capitalista, principälmente nos palses que ficaram à margem do processo de desenvolvimento capita lista orlginärio. Nesses palses, como o Brasil, que apresen- 
tam um passado colonial, a transformaçăo da agricultura apresenta certas particularidades importantes, sobre as quals fize mos algumas referênclas e que contribuem para o melhor entendi mento dos Capitulos 5 e 6 , que tratam, respectivamente, do de senvolvimento da agricultura regional de Taquaritinga e da eva lução da agroindústría do tomate na região estudada. No terceiro Capltulo fizemos uma discussão concel sobre excedente econômico e tentamos caracterizar três formas pelas quals o excedente gerado no setor agricola se transfere para o setor não agrícola da economia. Essa caracterização nos pareceu relevante porque salienta, de um lado, as condições da produçẽo egrícola, e portanto do excedente económico. e, de outro, o nfvel de dominaçäo que o capital industrial exerce sobre o setor agrícola.

No sexto capitulo, estudamos a agroindústria do tomate tal como ela se apresenta no momento no municipio de Ta-

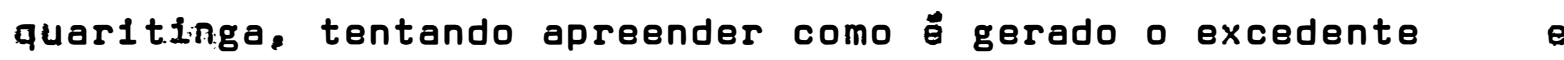
quals os artificios usados pelo capital industrial para apode rarase de parte desse excedente. 


\section{2 - O DESENVOLVIMENTO DO CAPITALISMO E A TRANSFORMAÇÃO DA AGRICULTURA}

Um dos aspectos da histórla do desenvolvimento do sis tema capitalista é a história da subordinação da agricultura à Indústria, vale dizer, ao capital Industrial. Essa 1déla expressa não só um ponto de partida para uma investigação que se pretenda realizar, mas principalmente o reconhecimento da hegemonia do capital, enquanto relação soclal que se reproduz, sobre as formas de produção anteriores, pré-capitalistas portanto.

A dinâmica do processo produtivo encontra-se, antes da afırmação do novo modo de produção, basıcamente na agricultura, mesmo porque a separação entre o campo e a cidade é incipiente nessa época. A partir do desenvolvimento do sistema capitalis ta, essa separação campo-cidade dä-se com maior vigor, provocan 
do uma mudança qualitativa na função dessa última: de um simples "locus" de onde se exercia a dominação politica da sociedade, as cidades transformam-se cada vez mals na base económico-produtiva da sociedade, não perdendo, é lóglco, mas fortale cendo o papel polftico que exerciam.

Segundo SINGER (1972: 4-5) . "A cidade, para subsistir, tem de dominar o campo, para dele extrair um excedente. Este domínio pode ser polftico, incluindo-se neste conceito a dominação ideológlca (...). As oferendas dos camponeses assę guram, nestas circunstâncias, a vida da cidade. ou então, cria-se uma autèntica interdependência entre campo e cidade. Neste caso, que só se configura como regra geral de relacionamento entre campo e cidade a partir da Revolução Industrial, a divisão de trabalho entre campo e cidade se define a partir da dinâmica da economia urbana (...) . Não é demais, portanto, falar de uma dominação do campo pela cidade, dominação esta que se torna mais completa quando ao seu aspecto politico se agrega o econômico".

Antes, a agricultura era o setor produtivo por excelèncla. Não só no que dizia respeito à produção de gêneros agrícolas básicos à população, mas também àquelas atividades complementares à atividade principal, a manufatura doméstica. Nesta, produziam-se artigos também de subsistēncia, como vestuário, etc., apresentando entretanto uma diferença fundamen tal com as atividades agrícolas: a terra, melo de produção in dispensāvel à essas ūltimas é escassamente utilizada na manufa 
tura. Essa diferença, bastante öbvia, é importante para o en tendimento das transformações que se farăo na antiga ordem prọ dutiva. A incipiente indústria doméstica rural val paülatina mente transformando-se até culminar em atividades quase que ex clusivas da população ocupada nas cidades. Com a crescente separação entre a cidade e o campo, acentua-se igualmente a di visão social do trabalho. Em última instância, essa divisão do trabalho é fundamentada na disponibilidade de meios de produção em um local e outro. Assim, as atividades urbanas são aquelas nas quals o uso do fator terra é dispensável, ou seja, no urbano desenvolve-se a indústria manufatureira.

E nessa última onde primeiramente tém lugar as trans formações advindas da emergência do modo capitalista de produçäo. As técnicas produtivas são continuadamente revolucionadas. culminando na transformação das antigas manufaturas em grandes Indústrias capitalistas. 0 processo de industrializa ção ocorre "pari passu" com a urbanização, e a divisão social do trabalho é cada vez mais intensa, levando a uma separação total entre cidade e campo.

Em determinado momento do processo de desenvolvimento do sistema capitalista, as relações de produção que lhe são tipicas começam a fazer-se presentes também na agricultura. A Introdução de relações capitalistas na produção agrícola obede ce às próprias necessidades do sistema que se expande. Como explica GARCIA (1976:5-6): ".. com a divisão do trabalho (cam po-cidadel alarga-se o comércio e incentiva-se a produção de 
mercadorias; com a industrialização e a urbanização em larga escala é aumentada a demanda de alimentos por parte da população urbana em constante crescimento, aumentando o preço dos produtos agrifcolas, estimulando o aproveitamento das terras de forma mais intensiva e mais produtiva, o que permite baixar-se os preços dos produtos que entram na reprodução da força de trabalho, que servem de matéria-prima lndustrial e ainda aumen ta o poder da competição no mercado externo. Aumenta-se o tamanho das plantas de fábricas processadoras de produtos agrí colas, estimulando-se a grande produção também no campo. E hả ainda a constante demanda industrial por força de trabal ho, que haverá Je ser suprida pelo campo".

A produção sofre uma. enorme transformação. Suas antigas técnicas produtivas são aprimoradas, substituídas por técnicas modernas e mais eficientes. A produção é organizada de forma mais racional. Todas as antigas condições são mo dificadas, dando lugar à organização tipicamente capitalista da agricultura.

Essas transformaçães não são suaves e indolores para os representantes da antiga ordem social. Pelo contrário, so bre um contexto de acumulação primitiva de capital, os melos pelos quals são geradas as condiçöes para o desenvolvimento ca pitalista são cruéis. o nücleo do processo é a expropriação do camponês de seus melos de produção, para que lhe reste somen to a força de trabalho,e assim, ter de vendê-la para continuar subsistindo. Segundo GARCIA $\left(1976_{b}: 3\right)$ esse processo caracteri - 
za-se, fundamentalmente, ".. pela negação das condições obję tivas de realização do trabalho independente. não sendo portan to, uma expropriação de excedentes. Expropriam-se os meios de pradução como condições necessárias para a posterior expropriação do excedente como forma de incrementar (mais-valia) os meios de produção apropriados concentrada e privadamente e em busca de valorização (capital)".

Através dessa expropriação, criam-se duplamente as condições da expansão do modo capitalista de produção: de um lado, a apropriação de uma parcela do trabalho empregado na produção de mercadorias, e de outro a possibilidade da realiza ção desse trabalho excedente - diga-se mais-valia - em novo capital, já que, com a destruição da antiga estrutura produtiva, destroem-se também as condições da existência da indústria doméstica, criando-se um mercado no qual penetrarão cada vez mals as mercadorias produzidas nas modernas indústrias.

Quando se pensa esse quadro teórico no caso do desen volvimento capitalista brasileiro, ou de qualquer outro pals em condições semelhantes às do Brasil, deve-se levar em conta as condições particulares em que se dá a expansão capitalista. o esquema geral não se modifica, mas a ele devem ser acrescentados determinados aspectos que se configuram como importantes para a melhor compreensão do problema.

o Brasil não teve um passado pré-capitalista idêntico ao dos palses da Europa Ocidental, origem e palco da Revolu ção Industrial do Século XVIII. A falta desse passado histó- 
rico, juntamente com as condições em que se deu a colonização, e consequentemente, a formação de nossa base econômica, levam a uma sërie de "distorçöes" se comparadas ao modelo clásicico do desenvolvimento do capitalismo.

E necessário termos em mente que nosso processo de Industrializaçãc é relativamente tardio, e até certo ponto,pre cedido pela urbanização. As cidades brasileiras, até pelo me nos o Inf́lo desse século, eram pouco industrializadas. Nelas se exercia o poder da oligarquia rural brasileira, comprometida com a produção agrícola de gèneros exportáveis e preocupada com a manutenção de sua hegemonia polftica na sociedade brasileira. De qualquer maneira, os núcleos urbanos formavam um mercado interno que era suprido em geral por produtos industriais importados.

Com a transformação da cidade, ela passa agora a tor nar-se produtiva, e a partir de então a divisão de trabalho en tre cidade e campo torna-se mais acentuada. Mas, de acordo com SINGER (1972:25), "... essa divisão estava fundamentalmen te viciada pelas relaçōes de exploração prë-existentes. Os me canismos pelos quals a cidade extrafa o excedente alimentar no campo, sob a forma de tributos. remuneração por serviços de in termediação (lucros comercials e juros) e renda da terra, meca nismos herdados do período colonial e aperfelçoados após a Independência, não foram appolidos de uma vez pela industrialização. Dessa maneira, a fontra-partida de produtos industriais oferecidos pela cidade em troca do excedente alimentar obtido 
no campo tendia a ser muito pequeno basicamente devido ao reduzido poder aquisitivo da população rural. Só num estágio muito mais avançado de industrialização, quando a cidade cres ce a taxas elevedas, expandindo aceleradamente sua demanda por alimentos e matërlas-primas agricolas ou extrativas,é que as velhas formas de exploração do campo são parcialmente aban donadas, surgindo nas áreas de melhor acesso ao mercado uma a gricultura capitalista, cujos produtos alcançam preços que co brem seus custos e proporcionam ao capital taxas adequadas de lucro".

A Industrialização deu-se, assim, quase que à margem do campo. A indústria rural, ainda relativamente forte na agricultura, Impedia a formação de um mercado rural a ser atendido pelas mercadorias produzidas pelo setor industrial. Por outro lado, a esse não Interessava o mercado interno rural, pols as possibilidades de acumulação eram bem maiores no mercado constitufdo pelas classes de altas rendas existentes nas cidades. Segundo OLIVEIRA (1974:19), "A Indústria, como tal, nunca precisou do mercado rural como consumidor, ou melhor dizendo, nunca precisou do mercado rural para viabili zar-se. (...) A orientação da indústria fol sempre e princi palmente voltada para os mercados urbanos não apenas por razöes de consumo mas, primordialmente, porque o modelo de cres cimento industrial seguido é que possibilita adequar o estilo desse desenvolvimento com as necessidades da acumulação e da realização da mais-valia ..." . 
Do lado da agricultura propriamente dita, vemos que as condiçōes para a expansão do sistema capitalista também são dificultadas em nosso caso. Nossa condição de colónia de exploração, com uma utilização importante de mão-de-obra escrava, retardou o desenvolvimento do capitalismo. A outorgação da Lei de Terras em 1850 é tido como um importante marco no sentido da transformação das terras em equivalente de mercadoria. Entre outras colsas, esse lel regulava o modo de ocupação das terras devolutas, promovia a legitimação das que haviam sido ocupadas e proibia as aquisiçöes de terras senão por compra. E certo que não fol a lei em si que estabeleceu a propriedade capitalista da terra, mas é inegável a importància da Lel de Terras de 1850 nessa transformação. Ao mesmo tempo que a lei regulariza institucionalmente uma situação já exis tente de fato - no caso o caráter capitalista da propriedade da terra, ela contribui para a criação de condições que assegu ram essa situação.

Porém, ainda por muito tempo o sistema capitalista encontrava obstáculos para se afirmar como tal. A própria d ficuldade de fiscalização do imenso território brasileiro, com vistas ao cumprimento da Lei de Terras é um aspecto a ser considerado. A farta disponibilidade de terras desocupadas no Brasil tornava na prática a lei ineficaz, o que permitia a ins talação de ocupantes ou posselros que constantemente tendiam a reproduzir relaçōes não capitalistas de produção. Desse prọ cesso de ocupação é que resulta parte da infinidade de peque - 
nos proprietârios e outras categorias existentes no meio rural brasileiro. Se a esse problema juntarmos o fato da exis tência do regime do colonato, que perdurou durante uma grande fase de nossa agricultura, percebemos que a expropriação dos meios de produçăo daqueles que os trabalham, fundamental para a posterior expropriação do excedente, razão de ser do sistema capitalista, é dificultada em nosso caso concreto. Segundo BRANT (1975:107), "A possibilidade de se reconstituir a peque na produção, a partir do excedente de força de trabalho originado do próprio desenvolvimento do capitalismo, está presente sempre que haja um grau insuficiente de utilização flenamente capitalista da terra. Tal é a natureza dos pequenos cultivos de subsistência que surgem nos intersticios da grande produção agrícola em vários países".

Entretanto isso não impediu, como observa GARCIA (1976b:5) "... que houvesse acumulação de capital no Brasil. E esta acumulação se deu a partir da subordinação de formas não capitalistas de produção aos interesses do capital. Sem dúvida alguma, esta não é a maneira própria do capital se reproduzir. mas estas maneiras passam a ser as únicas viáveis, nu ma certa etapa histórica, enquanto o capital não tem força suficiente para conquistar a própria produção introduzindo as re lações sociais que lhe dão conteũdo".

Tais considerações devem ser levadas em conta quando se pensa no desenvolvimento capitalista brasileiro especialmen te no que diz respeito a sua expansão na agricultura. Essa ex 
pansão mostra-se hoje bastante desigual. Há setores em que as possibilidades de acumulação, por serem maiores, levaram a uma preponderância das relações capitalistas de produção. Nes ses setores, a subordinação da agricultura no capital é total. Em outros setores entretanto, o desenvolvimento das relações capitalistas mostra-se incipiente, lento. Isso não significa entretanto, que o capital não domine a agricultura. só que essa dominação se faz de forma indireta.

Esse é um dos pontos da problemática do relacionamen to entre agricultura e industrialização no Brasil, uma vez que a existência e manutenção desses padrões de produção aparentemente não capitalistas na agricultura brasileira chegam a configurar uma situação de "atraso rural". Pois bem, MARTINS (1975:39), analisando o problema da modernização agráría e in dustrialização no Brasil, afirma que "A situação agrária, tal como foi descrita, não constitui uma 'aberração' ante o desenvolvimento atingido pela sociedade urbana brasileira. Antes, - desenvolvimento urbano, particularmente o da economia industrial, só foi e tem sido possivel graças à existéncia de uma economia agrária estruturada de molde a suportar e absorver os custos da acumulação do capital e da industrialização".

o que se depreende da citação acima é que, se de fato a agricultura configura uma situação de "atraso", esse não existe por uma questão de resistência à mudança, mas sim porque o desenvolvimento industrial brasileiro necessita que assim seja. 
Aliàs. é baseado nesse distanciamento que se tem pen sado a economia brasileira como dualista. Mas, como muito bem coloca OLIVEIRA (1974:19-20). "... não é simplesmente o fato de que, em termos de produtividade, os dois setores - a gricultura e indūstria - estejam distanciando-se, que autoriza a construção do modelo dual; por detrás dessa aparente dua lidade, existe uma integração dialética. A agricultura, nesse modelo, (...) tem uma contribuição importante na compatibil1zação do processo de acumulação global da economia (...) . Longe de um crescente e acumulativo isolamento, há relações es truturais entre os dols setores que estão na lóglca do tipo de expansão capitalista dos últimos trinta anos no Brasil".

A presença de relaçōes de produção não tipicamente capitalistas deve portanto ser explicada como sendo o resultado de uma determinada forma de dominação do capital. A existência dessas relaçōes tem dado margem à análises que previlegiam a agricultura tradicional no contexto da agricultura brasileira, realçando a importância da existência de relações não tipicamente capitalistas no meio rural.

DUARTE e QUEDA (1974:95), por exemplo, colocam que "... ao mesmo tempo que se costuma produzir a baixissimos nívels de produtividade e se configura uma situação de miséria da população aglomerada no minifúndio, a 'superpopulação' é ne cessária para manter baixo o nível de remuneração da força de trabalho agrícola, e, indiretamente, da força de trabalho não agrfcola, elevar a renda territorial, permitir a extração dire 
ta de excedente sem variaçōes profundas ante rebaixamentos dos preços dos produtos agricolas e manter abastecidas as cidades. Enfim, trata-se de atender às necessidades de acumulação no campo e na cidade".

Essa "funcionalidade" da agricultura tradicional não significa - è Importante frisar - que o sistema capitalista se submeta às formas de acumulação existentes na agricultura a té então, ou que o capitalismo não se torne hegemōnico na so cledade como um todo, já que as relações de produção que lhe são tipicas não se generalizam. Basta citar BRANT (1975:110): "Acreditar que uma formação social só se define como plenamente capitalista a partir da generalização do trabalho assalaria do e da concentraçāo e centralização do capital em todos os ra mos da produção à uma suposição algo simplista. Se a própria lögica do desenvolvimento capitalista supõe essa generalização. extensiva no limite (...) , o desenvolvimento histórico concre to não obedece em parte alguma a essa 'lóglca' linear. 0 desenvolvimento do capitalismo significou em todos os paises o movimento contrário entre seus pressupostos e suas consequên cias (...). Assim, a dominância do modo de produção capitalista não significa que as relações tipicas do capitalismo mais avançado sejam generalizadas ou quantitativamente predominan tes. Tampouco significa que a articulação entre as diversas formas de produção se faça de modo harmônico, ou 'funcional'. A contradição e a reposição necessária de forma 'atípicas' são uma marca do desenvolvimento do capital em toda parte". 
A questão da articulação de diversas formas produtivas para a ecumulação capitalista não se esgota ainda nesse ponto. BRANT (1975:117) faz uma observaçāo essenclal: "Se é importante determinar como a acumulação se dá em uma variedade de formas especificas, é também importante verificar como essas formas näo são apenas um produto do desenvolvimento histórico do capitalismo, mas também um obstáculo ao seu desenvolvi manto ulterior".

Essa questão nos parece de extrema importância na problemática da "funcionalidade" da agricultura atrasada, uma vez que nos permite enxergar a agricultura tradicional näo como uma solução para as contradições do sistema capitalista,mas sim como um aspecto dessas mesmas contradições, geradas pelo movimento do capital. 
30 .

3 - 0 PROBLEMA TEORICO DA EXTRAÇAOO DE EXCEDENTE ECONÔMICO

o problema da extração, pelo setor industrial, de um excedente econômico gerado no âmbito da produção agrfcola, nos parece o ponto essencial na problemática agricultura-industria, uma vez que o mesmo é o determinante fundamental dos aspectos que a questão envolve. Para os fins de nosso trabalho, discu tiremos mals especificamente a extração de excedente pela indústria, ou o capital que ela representa, que processa diretamente a matéria-prima produzida pela agricultura.

Convém, de infcio, definir algumas categorias concei tuals com as quals vamos trabalhas. 0 concelto de excedente aqui utilizado difere substancialmente do utilizado pela análi se marginalista, que identifica excedente económico com poupan ça, ou seja, um não-dispêndio da renda gerada, cuja magnitude 
é resultado de um comportamento subfetivo, e determinado sempre a posteriori.

o conceito por nós utilizado é aquele derivado da teo ria marxista. De acordo com MARX (1975a:241-242), ".. o tra balhador, durante uma parte do processo de trabalho, só produz - valor de sua força de trabalho, 1sto é, o valor dos meios de subsistēncla que lhe são necessărios. Produzindo ele num sistema que se fundamenta na divisão social do trabalho, não produz diretamente seus meios de substência, mas um valor (...) 1gual ao valor dos seus meios de subsisténcla ou ao dinheiro com que os compra (...). Chamo de tempo de trabalho necessário es sa parte do dia de trabalho na qual sucede essa reprodução (da força de trabalhol, e de trabalho necessário o trabalho dispendido durante esse tempo (...). 0 segundo período do processo de trabalho, quando o trabalhador opera além dos limites do tra balho necessário, embora constitua trabalho, dispêndio de força de trabalho, nào representa para ele nenhum valor. Gera a mais-valia, que tem, para o capitalista, o encanto de uma criação que surgiu do nada. A essa parte do dia de trabalho chamo tempo de trabalho excedente e ao trabalho nela dispendido, trabalho excedente".

A forma como o trabalho excedente é extraida do produ tor direto (do trabalhador), distingue por si só as diversas formaçōes econômico-sociais. No regime do feudalismo, por exemplo, o trabalho excedente aparece na corvéia, e, inclusive, - trabalho necessário encontra-se claramente separado do traba- 
lho excedente. 0 primeiro é efetuado no próprio terreno do camponês, enquanto o segundo é realizado nas terras pertencentes ao senhor feudal. Jä na sociedade capitalista, a forma em que aparece o trabalho excedente é a da mais-valia, e a separação en tre os dols tempos dispendidos no trabalho não é clara e evidente como na corvëia.

Sendo o produto social (P) igual à soma do capital cons tante (c) mais o capital variável (v) gastos na produção, e mais a mais-valia $(\mathrm{m})$, temos que

$$
m=P-(c+v)
$$

ou seja, na sociedade capitalista, o excedente económico se confunde com a mais-valia, sendo essa simples solidificação do trabalho excedente.

0 excedente econômico assim definido, como trabalho ex cedente ou mais-valia, não depende de nenhum comportamento subje tivo, sendo gerado objetivamente no processo de produção capitalista.

E mister referir-se à distinção entre mais-valia absoluta e relativa. Enquanto que a produção da primeira dá-se exclusivamente em função do aumento da jornada de trabalho, a se gunda surge de uma transformação ao nível do processo tēcnico de trabalho, com a consequente alteração na relação quantitativa en tre tempo de trabalho necessário e excedente. Como coloca MARX (1975:585), "A produção da mais-valia relativa pressupõe, por tanto, um modo de produção especificamente capitalista, que, com seus mëtodos, meios e condições, surge e se desenvolve, de inf- 
c10, na base da subordinação formal do trabalho ao capital. No curso desse desenvolvimento, essa sutordinação formal é substituIda pela sujeição real do trabalho ao capital".

o processo da aplicação do excedente económlco em novo capital o que se chama acumulação de capital. Não se con fundem portanto excedente econômico e acumulação de capital,sen do esse últımo conceito pertinente àquela parte da ma1s-valia transformada em novo capital. Nem todo o excedente ë por conseguinte acumulado. Uma parte dele é consumida como renda pe10 capitalista.

Ademais, "o capitalista (...) que extrai diretamente dos trabalhadores trabalho não pago, materializando-o em mercadorias, é quem primeiro se apropria dessa mais-valia, mas não ẽ o último proprietário dela. Tem de dividi-la com capitalistas que exercem outras funções no conjunto da produção social, com os proprietários de terra, etc. A mals-valia se fragmenta assim em diversas partes. Suas fraçōes cabem a dfferentes catego rias de pessoas e recebem por isso formas diversas, independentes entre si, como lucro, juros, ganho comercial, renda da terra, etc". MARX (1975a:658).

Apás essa breve discussão metodológico-conceitual,pas saremos a examinar de que maneira, ou por que melos, o excedente econômico gerado no âmbito da produçăo agricola, ou parte de le, $\vec{e}$ apropriado pelo setor não-agrícola.

E possivel distinguir três formas pelas quals se dá essa transferência. 
A primeira, na qual a indústria de processamento produz a sua própria matéria-prima, ou seja, é ela mesma a proprie tãria dos melos de produção empregados na obtenção da matéria prima. Nesse caso, a indústria explora diretamente a terra,se ja como proprietária, seja como arrendatária.

MARX (1975a:577-578) diz que "A indústria moderna atua na agricultura mals revolucionariamente que em qualquer outro setor, ao destruir o baluarte da velha sociedade, o campo nês, substituindo-o pelo trabalio assalariado (...). Os méto dos rotineiros e irracionais da agricultura são substituidos pe la aplicação consciente, tecnológica, da ciência. 0 modo de produçāo capitalista completa a ruptura dos laços primitivos que, no começo, uniam a agricultura e a manufatura. Mas, ao mesmo tempo, cria as condições materiais para uma síntese nova, superior, para a união da agricultura e da indústria ..." .

A situação a que estamos nos referindo difere um pouco daquela com que se preocupava MARX. Na verdade, este autor estava-se referindo a um contexto em que, dado um desenvolvimen to bastante intenso do modo de produção capitalista, a agricultura seria revolucionada no que diz respeito a suas técnicas de produção, chegando ao ponto de tornar-se um simples ramo da indústria, ou seja, a aplicação do capital na agricultura se daria sob as mesmas condições e sujeitas às mesmas leis que em ou tros setores.

Porém, segundo MARX, o capitalista que investiria seu capital na agricultura sería o arrendatärio, e não o proprietá- 
rio da terra. Aos proprietărios caberia a renda da terra, categoria que MARX estuda com profundidade. No nosso caso, o prôprio possuidor do capital aplicado na indústria é o proprietário da terra. De qualquer forma, independentemente da existência ou não da renda da terra, a consequêncla do desenvolvimento do capitalismo no campo $\vec{e}$ a industrialização da agricultü ra, a sintese nova que é a união da Indústria com a agricultura. Neste caso, a extração do excedente gerado na agricul tura se dá de uma forma direta, pols o trabalhador agricola en contra-se subordinado diretamente ao capital industrial.

Como 1lustração, podemos tomar a agroindústria açucareira. Por uma série de motivos históricos, entre os quais uma forte intervenção governamental, discutida por QUEDA (1972), aliada às características tecnológicas da produção da cana-deaçūcar, principalmente àquelas que dizem respeito à economias de escala, os capitalistas do açúcar detém a propriedade da malor parte das terras onde produzem a matéria-prima que processam.

GEBARA (1976:27-28) afirma que "A empresa açucareira funciona em moldes tipicamente capitalistas e assim procura maximizar seu lucro, trabalhando numa escala ótima de produção. Para tanto, a usina de açúcar deve ter grande volume de produ ção de cana para garantir seu pleno funcionamento. Assim, pro cura adquirir terras para sua prōpria produção de cana-de-açú car ..." . 
Talvez o aspecto mals importante quando se pensa, hoJe, sobre a agroindūstria canavie1ra, são as condiçōes tecnolöglcas da produção da cana-de-açūcar, realizada de uma forma capitalista. Esse desenvolvimento tecnológ1co, resultado do pro cesso de concentração e centralização de capital no ramo, por s1 só discrimina os pequenos fornecedores de cana-demaçücar, que não têm porte suficiente para os investimentos a serem real1zados, devido principalmente à existêncla de economias de escala. Apesar da legislação canavielra estabelecer que as usinas devem processar a cana de fornecedores e pröpria em proporçōes, esse problema é facllmente superado na medida em que as usinas, como empresas Industria1s, näo têm em seu nome todas as terras que lhe pertencem de fato. Segundo GEBARA (1976:28) "A usina normalmente é uma pessoa juridica e as suas äreas de cana fazem parte das fazendas pertencentes às pessoas que detém a propriedade industrial". O resultado é que as us 1 nas mantém sua Independêncla no que diz respelto ao fornecimento da matéria-prima que processam.

o fato é que a agrolndüstria açucareira configura-se hoje como um setor em que as relações entre a Indüstria e a agricultura caminham no sentido de uma transformaçäo desta ült1ma num simples ramo da primeira.

Como af1rma IANNI (1976:36), "A usina é uma fäbrica fora do lugar, da cldade, no campo. Parece inserida no proces so de reprodução do capital agrár1o. Na usina, o capital agrá rio o capital industrial aparecem conjugados, um subsumindo 
- outro. De longe, vista no campo, a usina parece engulida pe lo canavial, a fábrica pela planta, a Indústria pela agricultura. Mas o que ocorre é o Inverso, reverso. Na agroindús tria açucareira, o capital Industrial Instalado no campo confere ao capital agrărio as suas cores e os seus matizes".

As relaçöes e estruturas de apropriação são, na usina, entendidas como um complexo que une a fäbrica e a plantação, se melhantes a qualquer outro ramo da indüstria.

Uma característica Importante, porém, e̊ aquela assina lada por IANNI (1976:55), de que "... na agroindústria açuca reira ocorre a exploração combinada da mais-valia relativa e da mals-valia absoluta. Na usina, onde tudo está mecanizado, a massa de força de trabalho tem diminuido, em termos relativos, em confronto com o capital empregado em máquinas, equipamentos, e organizações. AI cresce a composição orgânica do capital, 1s to ë, a proporção de tecnologia (máquinas, equipamentos, etc.) em face da força de trabalho. Esse é o contexto soclal e técnico da produção de mals-valia relativa, quando a tecnologia po tencia a produtividade da força de trabalho. Mas também se estende a jornada de trabalho na época da safra. Na safra, em geral, o funcionamento da usina $\bar{e}$ Ininterrupto. E as turmas de trabalhadores se revesam de doze em doze horas. Isso sign1 fica que cada operārlo trabalha as oito horas normals e mals quatro. Esse é o rítmo e a exigêncla do clclo da reprodução do capital (...). Nesse caso, tende a combinar-se a produção de mals-valia relativa com a mais-valia absoluta. Na lavoura 
tambēm combinem-se as duas formas de mais-valia. A mecanização, em sentido lata. se estende: aplicam-se cada vez mals tra tores, caminhões, fertilizantes, defensivos, etc. Na época da safra, no entanto, a Jornada ultrapassa a oito horas, e o ritmo do trabalho é intensificado. O fato de que o cortador ganha por tonelada cortada, leva-o a empenhar-se bastante na fa1na do corte".

A segundo forma através da qual o excedente é transfe rido da agricultura para a indústria é aquela na qual o capital Industrial näo produz a matêria-prima que industrializa.

A matēria-prima a ser industrializada ë produzida por produtores Independentes, sendo essa produção realizada por pe quenos agricultores em que a força de trabalho utilizada é a do produtor direto e de seus dependentes. Quer dizer, o emprego de mão-de-obra assalariada inexiste, ou existe em muito pouca quantidade.

Esse sistema apresenta semelhança com a economia camponesa, 1sto é, a exploração parcelária da terra pela massa tra balhadora rural, base econômico-social do antigo sistema feudal. A essa economia camponesa se sobrepunha, como diz PRADO JR. (1974:32), "... uma classe nitidamente diferenciada e privilegiada (...) que explora a massa camponesa e se apropria do so breproduto do seu trabalho, atravēs de privilégios que lhe são assegurados pelo regime social e politico vigente, e que se con figuram e realizam sob a forma de relação de dependência e subordinação pessoal, do camponês". 
Segundo TAVARES DOS SANTOS $(1975: 172)$, Wo camponēs Ë personificeção de uma classe social definida pela forma de pro dução simples de mercadorlas, forma de produção na qual o produtor direto, ao mesmo tempo, detém a propriedade dos melos de produção e trabalha com esses melos de produçäo".

Normalmente, a quantidade de terra que possu1, seu principal melo de produção, é pequena, donde se confunde, mu1tas vezes erroneamente, camponès com pequeno proprietário. Er roneamente porque, se de um modo geral pode-se dizer que os camponeses são pequenos proprietärios, o 1nverso nem sempre है verdadeiro. Multas vezes, pequenós proprietários são verda delros capitalistas, produzindo em condiçōes de reproduçāo ampliada. Jå o camponês é, nas palavras de KAUTSKY (1968:165) "... um trabalhador, pols não vive do produto de sua empresa, mas do produto de sua própria atıvidade. 0 seu gênero de vida é o de um assalariado. Tem necessidade da terra como um melo para ganhar o pão como operário, e não para dela tirar qualquer lucro ou renda fundiăria".

Entretanto, o camponês se Insere na sociedade capitą lista, sendo redefinido a cada momento pelas transformaçōes ad vindas da expansão do sistema capitalista.

Essa redefinıção da propriedade camponesa e sua vinculação ao mundo capitalista não significa, porém, sua trans formação numa relação social de produção capitalista tIplca. Dado o fato do produtor, por um lado deter a posse da terra e dos seus melos de trabalio, e por outro ser o trabalhador que 
aciona seus próprios melos de produção torna-se problemático caracterizar tal relação de produça como capitalista.

Sem entrarmos em malor profundidade na discussão, Im portante sem dúvida, da caracterizaçäo desses relaçōes de pro dução. Interessa-nos apreender como se transfere um excedente gerado na produçāo agrícola realizada por esses produtores. Ora, na medida em que esses produtores não utilizam trabalhadores na produção, a nāo ser ocasionalmente, só á pos sivel extrair um excedente do trabalho do próprio produtor e de seus familiares. Ou seja, o excedente apropriado pela In düstria $\check{\text { o }}$ trabalho excedente do produtor direto.

Podemos, como 1lustração, cltar a produção de uva como matéria-prima para as Indüstrias de vinho, no Rio Grande do Sul. ou mesmo a produção de fumo para as Indústrias de c1garros.

Em ambos os casos, os produtores da matéria-prima são pequenos produtores, usando basicamente o trabalho fam1 liar na produção. Ambas as culturas exigem um uso intensivo de mäo-de-obra durante quase todo o ano, sendo, desse modo, a ocupaçäo básica das famillias, alēm de uma produção em separado destinada à subsistência das mesmas.

Ao que tudo Indica, os produtores ficam totalmente à mercé das indústrias, única compradora de seu produto, sofrendo uma expropriação por parte desta ültima.

Contudo, essa expropriação não significa que não ha Ja possibilidade de lucro ou de renda diferencial. Como co- 
loca TAVARES DOS SANTOS $(1975: 172)$, "A renda difererrcial será gerada pelo camponês cujo trabalho se realiza em condições mals favoráveis. Todavia, a apropriação da renda diferencial gerada näo ë felta necessar Iamente pelo camponês, antes tende, em graus e formas variáveis, segundo cada situaçäo histórica concreta, a aer apropriada por outras classes ou fraçöes de classes".

Por último, a terceira forma em que se pode perceber uma transferência de excedente, é aquela em que o produtor direto detém a propriedade da terra na qual produz, mas não se assemelha com o tipo de produtor discutido no caso anterior.

A diferença fundamental é que há exploraçăo, com cer ta Intensidade, de trabalho alhe1o. As relações de produção dominantes săo capitalistas, sendo o produtor um pequeno capitalista que extrai mais-valia, ou trabalho excedente, de seus assalariados. Esse excedente, entretanto, não permanece, pelo menos não totalmente, no àmbito da produção agricola, sendo transferido para a Indústria pela atuação do capital Industrial, notadamente na comercializaçāo da matëria-prima.

Trata-se portanto de uma competição entre capitais a plicados em ramos diferentes de produçäo, o agricola e o Indus trial, em que este último frequientemente leva vantagem. Essa vantagem é conseguida, em última instâncla, porque é o capital industrial o mals concentrado, e portanto mais. uniforme, em fa ce dos vários capitais agrícolas pulverizados na agricultura. 
Sobre o processo de concentraçäo e centralização de capital, escreve MARX (1975a:727): "Os capitals grandes esma gam os pequenos. Adema1s, lembramos que o desenvolvimento do modo de produção capitalista aumenta a dimensão minima do capi tal Individual exigido para levar avante um negóc1o em cond1 çōes norma1s. Os capitals pequenos lançam-se, assim, nos ramos de produção de que a grande indústria se apossou de mane1ra esporảdica ou 1ncompleta. A concorrêncla acirra-se e acaba sempre com a derrota de multos capitalistas pequenos, cujos capita1s ou soçobram ou se transferem para as mãos do vence dor".

Essa concorrêncla, apesar de ser mals acirrada dentro de um mesmo setor da economia, ocorre também entre cap1 tals aplicados em setores diferentes, como é o caso que esta mos analisando. Porêm, hä certas particularidades que devem ser consideradas.

Na luta de Interesses entre a Indústria de processamento e os produtores da matéria-prima, a primelra impöe a sua razão, dominando quase que completamente os segundos. Mas essa dominação encontra um limite, que é a desistência do cap1 tal agrícola da atividade produtora da matéria-prima, da qual a Indústría depende.

A agroindústria do tomate, objeto de estudo deste trabalho, serve como 1lustração à tercelra forma de extração de excedente entre os setores envolvidos. 
A Indústria fornece aos produtores rurals uma sêrie de insumos a fim de garantir o abastecimento da matéria-prima. Após garantida a produção, é evidente a montagem de todo um es quema que objetiva "amarrar" os produtores à Indūstria. Essa "amarraçäo" permite à Indústria planejar adequadamente sua safra, eliminando problemas que prejudicariam a industrialização, permitindo a auferição de lucros mals elevados. Os contratos, por exemplo, estabelecem as épocas e respectivas äreas de plan tio do tomate, evitando dessa maneira a concentração da produção em determinada época. Para os produtores, isso também não deixa de ser interessante, já que evita problemas de escoa mento da safra. Mas percebe-se que esse tipo de politica é fixado mais de acordo com as necessidades de acumulação de capital da indüstria, que da agricultura.

Na comercialização propriamente dita, desde a fixa ção do preço do tomate até a pesagem nas balanças da indústria, os produtores são descaradamente lesados. Há anos, porém, em que a falta de matéria-prima, decorrente de razões climáticas, por exemplo, leva a que as indüstrias processadoras mostrem-se complacentes com os produtores, justamente para não elimtinálos nos anos seguintes.

Resta dizer, quanto à discussão sobre essas três for mas de extração de excedente da agricultura pela indústria de processamento, que elas não são exclusivas, podendo-se encon trar, o que normalmente acontece, formas combinadas de apropríação. 
Assim, Percebemos que na agroindístria de tomate existem produtores que se assemelham bastante com o produtor de uva do Rio Grande do Sul, assim como neste último caso é possí vel encontrar-se pequenos capitalistas, tais como os produto res de tomate. Mesmo no caso da agroindüstria açucareira, en contramos, entre os fornecedores de cana, alguns grandes capitalistas, outros pequenos, e mesmo produtores camponeses.

o esforço de caracterizar formas diferentes de trans ferência de excedente entre os setores deve ser encarado com uma tentativa de sistematização para, com essa sistematização, evitar-se confusões advindas, principalmente, da generalização de casos particulares estudados. 
O município de Taquaritinga pertence à Divisão Regio nal Agrícola (DIRA) de Ribeirão Preto, do Estado de São Paulo, localizando-se na região mais conhecida como Mëdia-Araraquaren se, apesar de, pela classificação do INCRA, estar situada na microregião homogênea Serra de Jaboticabal.

Sua fundação data do ano de 1868 , quando ocorreu a doação de uma gleba de 64 alqueires para a formação do patrimō nio de São Sebastião do Ribeirãozinho, elevado à categoria de vila no ano de 1892 , e meses depois, no mesmo ano de 1892 , e levado à condiçăo de Município, denominando-se Ribeirãozinho. Em 25 de dezembro de 1907 é criada a Comarca de Taquaritinga. Taquaritinga dista 342 quilômetros da capital do Estado, através da Rodovia Washington Luiz - SP 310 - e 81 quí 
lômetros da cidade de Ribeirão Preto, no sentido Oeste.

São municípios limitrofes de Taquaritinga os seguintes: Monte Alto, Jaboticabal, Guariba, Santa Ernestinha, Dobrada. Matão, Itápolis, Fernando Prestes e Cândido Rodrigues.

Segundo dados do IBGE e da Secretaria de Economia e Planejamento, citados em JUNQUEIRA et alii (1972), o município de Taquaritinga tinha em 1960 um total de 24.417 habitantes, sendo 12.981 na Zona Rubana e 11.436 na rural, e, em 1970, um total de 27.532 habitantes, sendo 18.556 na Zona Urbana e na rural. A população rural, como podemos notar, sofre um de crëscimo absoluto, refletindo a intensa migração rural-urbana ocorrida nesse período em toda a região, que teve, e tem tido, um forte processo de urbanização a partir da última década.

o desenvolvimento de Taquaritinga deveu-se, fundamen talmente, ao grande impulso da cultura do café na região, ocor rido em fins do século XIX. As antigas áreas de produção, es pecialmente o Vale do Paraíba no Estado de São Paulo, mostra vam-se declinantes, e a este decilnio correspondiam fases de ascensão em outras zonas, de desbravamento recente, como a que estamos nos referindo. Sobre essa evolução cíclica do café, escreve PRADO JR. (1973:226): "o desenvolvimento da lavoura cafeeira do Brasil, desde o último decênio do século XIX, admirável no conjunto, fol entretanto multo irregular se conside rarmos as diferentes regiöes do país. Não houve de modo algum crescimento uniforme e harmōnico, e à expansão em alguns 
setores correspondeu o decínio, e mesmo o aniquilamento com pleto de outros (...), sucedendo-se em cada zona produtora, no espaço d poucos decēnios, uma fase ascendente seguida de outra próxima da decadêncian.

Toda a região do oeste paulista, e nela a Araraquarense, estava em fase de ascensão. Concorreu para isso a existência de terras férteis, topografia bastante regular, e um clima que se prestava não só à cultura em si, como tambēm aos braços que a trabalhavam, tendo os trabalhadores imigrantes europeus a ele se adaptado multo bem.

A expansão cafeelra que se alastra pelo oeste pau lista, parte de Campinas em direção a Ribeiräo Preto - ao norte - acompanhando as manchas de terras roxas existentes, quase contínuas. E em Ribelrão Preto que se forma o principal núclæo produtor de café - não só do Estado de São Paulo, como de todo o Brasil - tornando-se mundialmente famoso.

A partir desse nǘcleo, ele expande-se para todos os lados, especialmente para o oeste propriamente dito, qual seja, as regiōes de Araraquara, Catanduva e Jaboticabal.

E de presumir-se, portanto, que a formação de cafe zais na região de Taquaritinga é pouco posterior, datando do Início deste século. Segundo dados da Estatística Geral e A grícola dos Municípios do Estado de São Paulo, publicados em 1958, havia em Taquaritinga, no ano de 1935, 21 milhöes de pés de café, com idade variando entre 25 a 40 anos, o que nos leva a crer que pelo menos até 1910 o plantio de café no mun 
cipio foi intenso.

Essa fase eufórica da expansäo do café na região tem como consequéncia o grande surto de desenvolvimento das cidades do noroeste do Estado. Antes disso, a própria constituição dessas cidades - antigas vilas ou patrimônios - em municípios e comarcas é fruto da expansão do "ouro verde" pela regĩa.

Um fator importante, que acompanha a expansão do café, é a constituição de uma extensa rede ferroviāria no interior do Estado, ligando essas regiões não só entre si, mas, principalmente, com a capital do Estado e o porto de Santos, por onde o café produzido era exportado. A "chegada" da estrada de ferro nas antigas vilas e cidades era um importante fator de progresso das mesmas.

Porém, a par com essa expansão, começam a aparecer os primeiros sintomas de sua contrapartida: a super-produção, que acompanhará a economia cafeeira do Brasil por muito tempo.' Já em 1896 , segundo PRADQ JR. (1973), observar-seäo os primeiros sinals de desequilíbrios, tendo, no período de 1890 a 1900 , duplicado as plantações de São Paulo. Assim é que, conforme SIMONSEN (1973:230): "o Estado de São Paulo decretou, em 1902 , um imposto de $2.000 \$ 000$ sobre cada alqueire de cultura de café novo. Era, de fato, a proibição a novas plantaçöes. Esse dispositivo legal devia vigorar por um quinquênio, mas fol prorrogado ao cabo do seu turno por mais cinco anos". 
Essa lei não evitou, contudo, que as plantações exis tentes produzissem a enorme safra paulista de 1906 , contri buindo para uma drástica redução de preços. E de se imaginar que a partir dessa época diminuissem em muito as plantações de café na principal região produtora, que engloba Taquaritinga.

Politicas consagradas à estabilização de preço do produto são colocadas em prática, principalmente a compra de excedentes de produção, com vistas à formação de estoques regü ladores. Essas politicas resultaram basicamente do entendi mento havido naquilo que se convencionou chamar de Convênio de Taubaté.

Em junho de 1918 ocorreu a-grande geada que prejudicou seriamente os cafezais de São Paulo e, decididamente,a par tir de então, toda a região Paulista e Araraquarense quase que cessa seu plantio.

Nas Tabelas 1 e 2 temos uma idéia mais aproximada de como se encontrava a cultura do café nos cinco principais muni cipios produtores da região noroeste do Estado, no ano de 1942.

De imediato, chama-nos a atenção o fato de não existirem, praticamente, novas plantações na região envolvida. Além do mais, se atentarmos para o fato de que, como já foi men cionado atrás, havia em 1935 um total de 21.000 .000 de pés de café em Taquaritinga, percebemos que, sete anos depois, esse nümero reduz-se à metade, o mesmo devendo ter ocorrido nos de mais municfpios. O fato é que, com a erradicação dos cafezais mais antigos atingidos pela geada de 1918 , não houve mais 
estímulos a novas plantações, basicamente porque as possibilidades de lucro com a cultura encontravam-se reduzidas em face dos problemas enfrentados no mercado internacional.

TABElA 1 - Área com café, percentagem da área total e nümero de trabalhadores ocupados - 1942 - Principais munzefplos da região Noroeste - SP.

\begin{tabular}{llcc}
\hline Municipio & $\begin{array}{l}\text { Area com } \\
\text { café (ha) }\end{array}$ & $\begin{array}{l}\text { \% da ärea } \\
\text { total }\end{array}$ & $\begin{array}{c}\text { Nümero de } \\
\text { trabalhadores }\end{array}$ \\
\hline Taquaritinga & $13.171,5$ & 24,0 & 5.674 \\
Bebedouro & $12.475,8$ & 31,5 & 4.407 \\
Catanduva & $19.257,1$ & 41,9 & 8.686 \\
Jaboticabal & $12.960,4$ & 24,5 & 5.292 \\
Araraquara & $14.190,7$ & 15,2 & 7.747 \\
\hline
\end{tabular}

FONTE: Cultura do Café no Brasil - DNC.

TABELA 2 - Número e idade dos cafeeiros - 1942 - Principais municlpios da região Noroeste - SP.

\begin{tabular}{lcc}
\hline Municipio & $\begin{array}{c}\text { Número de cafeeiros } \\
(1.000 \text { pés })\end{array}$ & $\begin{array}{c}\text { de } 20 \text { anos } \\
(1.000 \text { pés })\end{array}$ \\
\hline Taquaritinga & 10.874 & 10.868 \\
Bebedouro & 10.293 & 9.454 \\
Catanduva & 16.021 & 15.865 \\
Jaboticabal & 10.623 & 10.509 \\
Araraquara & 12.889 & 12.452 \\
\hline
\end{tabular}

FONTE: Cultura do Café no Brasil - DNC 
Dois outros pontos chamam-nos atenção nas Tabelas 1 82 : a alta porcentagem da área total com a cultura e o número de trabalhadores ocupados na mesma. 0 primeiro ponto dá-nos uma idéia da predominância do café nessas regiões, ocu pando quase que totalmente as melhores terras disponíveis. 0 segundo ponto mostra-nos a intensa utilização de mão-de-obra, na cultura, não significando, entretanto, que a mesma seja constituida de assalariados puros, pois, como diz PRADO JR. (1973:228), "Na generalidade da lavoura cafeeira, em São Pạ lo em particular, adotar-se-á nas relaçöes de trabalho um sís tema que combina salariato (...) com o direito concedido ao trabalhador de utilização de certas äreas de terras em proveí to próprio. Havará, ao lado desse tipo de trabalhador lo co lono, como se chamaj, mas geralmente em número muito menor, o assalariado puro que será simples jornaleiro. Para todos a fazenda fornecerá resistência, mas não os instrumentos de tra balho. Estes aliás são muito simples, pois não passam da en xada s na cultura do café, que é planta permanente e cuja colheita é manual, não se emprega maquinaria".

Com o declínio da produção do café em toda a região, agravada sobremaneira com a grande crise de 1929-32, entra em colapso toda a economia regional. Esse colapso, porém, tem muito maior significado para os produtores de café, na maior parte, grandes produtores. E certo que a agricultura de ex portação era, e é ainda hoje, o "carro-chefe" da economia agri cola. Na medida em que ela entra em crise, todo o "hinter - 
land" que a cerca sofre com essa crise. Mas acontece que é exatamente nesses momentos de crise da economia exportadora, que o setor de subsistência encontra oportunidades para um maior desenvolvimento, adquirindo maior expressão. A crise de alguns é a saída do estrangulamento de outros. Como coloca PRADO JR. (1969:16), discutindo o relacionamento entre a grande exploração e o setor secundário das atividades rurais: "... o setor secundário se ampliará na medida em que, inversamente, a grande exploração, debaixo de cuja sombra ví ve, se expande ou se retrai, se consolida e prospera, ou, P旦 lo contrário, se debilita e decompōe".

E lógico que, como já dissemos acima, a crise dos senhores do café se expande por toda a economia regional. Tal ocorre principalmente porque todos os setores que traziam a fachada do progresso estavam bastante vinculados à economia cafeeira. E o caso do sistema de transportes, da rede bancá ria, ou daqueles envolvidos na comercialização do produto.

E perfeitamente imaginável supor que durante o auge do café a quantidade de dinheiro em circulação era maior, tra zendo reflexos no desenvolvimento do comércio como um todo. E na medida em que se interrompe parcialmente esse fluxo de dinheiro, o comércio também entra em decadência.

ZAMBONI (1976:3), num estudo sobre o distrito de I bitirama, no municipio de Monte Alto, fundado em 1900 , afirma que "A partir da construção da estrada de ferro, muito pọ sivelmente inspirada na riqueza que o café emprestava à re- 
gião, houve um aumento da população, e não tardou que um primeiro bar surgisse na vila que ia crescendo".

Esse tipo de estabelecimento, juntamente com outros, tais como barbearias, sapatarias, etc., sofre também um grande golpe com a decadência do café.

Entretanto, sem sombra de dúvida, a crise foi muito menos sentida pelos pequenos produtores rurais, ou pelos colonos, e mesmo pelos trabalhadores do café. Du, pelo menos, a percepção da crise por essas categorias foi diferente. Quando o café estava em seu apogeu, o trabalho era intenso, árduo, sufocante. Quando entra em declínio, o trabalho escasseia, mas a luta pela sobrevivência em seus pedaços de terra é redobrada, as agruras são as mesmas.

De um modo geral, a decadência do café quebra a ant ga estruturação econômica. Grandes fazendas são divididas, vendidas muitas vezes para a liquidação de dívidas, modificando-se a distribuição da posse da terra.

PRADO JR. (1972a: 227) afirma que "A pequena pro priedade desenvolveu-se em consequência das crises do café. 0 esgotamento do solo, a queda de preços, as dificuldades de exportação, esses são os verdadeiros fatores que contam. E deles que provém a ruína das fazendas e grandes domínios, e, em consequência, seu retalhamento, último recurso para sair das dificuldades".

Esse retalhamento, sem ser drástico, dá condições pa ra que o setor secundário da economia agrícola se desenvolva, 
e a região como um todo passa a ser, se assim podemos chamála, cerealista.

E digno de se mencionar, nessa transição, a evolução da agricultura algodoeira. Apesar da predominância do café, aquela cultura começa a crescer em importáncia em todo - Estado a partir principalmente de 1916 , segundo SINGER $(1974)$.

Na safra de 1938-39, Taquaritinga aparece como o $11^{\circ}$ produtor estadual de algodão, e sua comparação com outras localidades pode ser observada na Tabela 3 .

TABELA 3 - Produção de algodão em caroço - safra 1938/39 Alguns dos principais municlpios produtores do Estado de São Paulo

\begin{tabular}{lc}
\hline Município & Produção $(t)$ \\
\hline Taquaritinga & $4.251,5$ \\
Marilia & $18.913,9$ \\
Campinas & $9.140,3$ \\
Rio Preto & $7.008,5$ \\
Catanduva & $6.545,5$ \\
Jaboticabal & $5.952,9$ \\
\hline
\end{tabular}

FONTE: Anuário Algodoeiro. Bolsa de Mercadorias de São Paulo, 1941 .

A região com malor participação nesse sub-ciclo de algodão observado no Estado é a de Marflia, de desbravamento mais recente, e onde, portanto, a disponibilidade de terras para a lavoura era maior. Mas a região com a qual estamos 
nos preocupando é também intensamente cultivada com algodão. Essa cultura chegou inclusive a competir com o café, uma vez que eram plantados em terras distintas, já que nos cafezais formados o plantio intercalado é quase que impossivel.

Esse sub-ciclo do algodão aparece num momento provi dencial para a região. Assim é que a essa cultura destinamse os trabalhadores anteriormente ocupados com o café, e o despovoamento da região é até certo ponto contido.

A denominação de "cerealista" para a região,diz mui to mais respeito à falta de um produto de exportação que subs tituisse o café, que propriamente a um aumento da produção de cereais na região. Na verdade, com a queda do café, já a partir do infcio da década de 30 , cria-se uma vácuo na prodü ção agrícola durante pelo menos as duas décadas seguintes,men ção feita ao algodão, vácuo esse que somente a partir da déca da de 50 começa a ser ocupado pela laranja e pela cana-de-açú car.

Pela Tabela 4 podemos observar a evolução da produção agricola do municfpio de Taquaritinga desde 1935.

A análise da Tabela 4 deve ser feita com cuidado, $\underline{U}$ ma vez que na sua construção foram tomadas várias fontes distintas, e como se sabe, nem sempre elas são homogêneas, além de que o municlpio de Taquaritinga sofre um desmembramento en tre 50 e 60 - o distrito de Cândido Rodrigues passa à condição de municlpio. De qualquer maneira a Tabela dá-nos uma idéia da evolução agrícola do municfpio. 
TABELA 4 - Evolução da quantidade colhida dos principais produtos agricolas no municipio de Taquaritin ga, SP.

\begin{tabular}{|c|c|c|c|c|c|c|}
\hline Produto & 35 & 39 & $50^{A n}$ & $\begin{array}{l}0.5 \\
59\end{array}$ & 70 & 72 \\
\hline Café $(t)$ & 8.250 & 4.468 & 2.352 & 2.134 & 946 & 1.666 \\
\hline Arroz (t) & 1.860 & 1.116 & 3.716 & 2.007 & 2.422 & 9.923 \\
\hline Feijão (t) & 930 & 245 & 73 & 104 & 47 & 366 \\
\hline Milho $(t)$ & 7.200 & 3.954 & 3.851 & 3.951 & 8.517 & 5.549 \\
\hline Amendoim ( $t$ ) & - & - & 105 & 1.471 & 5.095 & 4.421 \\
\hline Algodão (t) & 3.390 & 11.397 & 2.126 & 2.399 & 443 & 2.175 \\
\hline $\begin{array}{l}\text { Laranja (1.000 } \\
\text { frutos) }\end{array}$ & 276 & 4.905 & 7.623 & 75.646 & 244.987 & 343.523 \\
\hline $\begin{array}{c}\text { Cana-de-açúcar } \\
(t)\end{array}$ & - & 2.927 & 2.825 & 32.746 & 115.243 & 320.112 \\
\hline $\begin{array}{c}\text { Goiaba (1.000 } \\
\text { frutos) }\end{array}$ & - & - & - & 307 & 19.188 & 48.000 \\
\hline FONTE: & $\begin{array}{l}\text { para } \\
1972 \\
\text { ios d }\end{array}$ & $\begin{array}{l}\text { os anos } \\
\text {; Estat } \\
\text { Estadc }\end{array}$ & $\begin{array}{l}\text { de } 19 \\
\text { stica } \\
\text { de Sa }\end{array}$ & $\begin{array}{l}39,195 \\
\text { Geŕal e } \\
\text { Paulo }\end{array}$ & $\begin{array}{c}\text { e } 1970 \\
\text { Agrícola } \\
\text { ara } 1935\end{array}$ & $\begin{array}{l}\text { INCRA } \\
\text { dos Mu }\end{array}$ \\
\hline
\end{tabular}

Os dados referentes à produção de tomate não estão in clufdos nessa Tabela pelo fato de que a esse produto dedicare mos um capitulo especifico deste trabalho.

Percebe-se claramente o declínio da produção de café no municipio. Em termos de produção, ela até certo ponto mantém-se até meados da década de 30 , pelo fato de ser uma cultura permanente e que dá uma produção razoável até a idade de 30-35 anos. Apesar do produto estar em crise no mercado inter nacional, com os preços bastantes baixos, erradicar os cafezais não era a melhor solução, além de ser uma operação difícil e o- 
nerosa. Ademais, como coloca FURTADO (1974:186-7)," ... o problema consistia menos em saber o que fazer com o café do que decidir quem pagaria pela perda. Colhido ou não, a perda existia. Abandonar os cafezais sem dar nenhuma indenização aos produtores significava fazer recair sobre estes a perda maior".

Nesta altura dos acontecimentos, a economia já havia desenvolvido uma série de mecanismos, cujo objetivo principal era transferir para a coletividade como um todo as perdas ad vindas do café. Ou seja, houve o que se convencionou chamar de socialização dos prejuízos.

Já referimos que durante pelo menos as duas décadas seguintes à de 30 , toda a região tem o seu setor de mercado externo praticamente estagnado, o que aumenta as possibilida des de um desenvolvimento autônomo do setor de subsisténcia. o setor de mercado interno, num primeiro momento, também se retrai violentamente, uma vez que ele dependia da economia exportadora.

Porém é exatamente essa ruptura entre o setor de mer cado interno e o externo que val aos poucos dando as condições para o desenvolvimento mais recente.

SINGER (1974:14-15) coloca muito bem essa questão quando diz que "De acordo com o funcionamento 'normal' da Eco nomia Colonial, o crescimento do setor de Mercado Interno é in duzido pela expansão do Setor de Mercado Externo. Ora. quan to o Setor de Mercado Interno permanece nesta situação, ele 
não faz mais que desempenhar um papel de fornecedor supletivo do fluxo de importações. 0 processo de desenvolvimento se inicia por uma ruptura estrutural, começando o Setor de Mercado Interno a crescer autonomamente ..."

Apesar do autor acima estar-se referindo ao Setor de Mercado Interno da Economia Colonial, a analogia é perfeitamen te válida para o nosso caso.

o ponto de vista que defendemos é o de que é justa mente essa fase "cerealista" da economia regional que fornece as bases, estas mais sólidas, para o posterior desenvolvimento da região. Em que pese toda a relativa estagnação da região, que se reflete inclusive no próprio crescimento das cidades lo cais, mesmo em termos populacionais, é durante esse período que se moldam e se desenvolvem as estruturas necessárias ao desenvolvimento mais recente verificado, muito menos artificial que o primeiro, menos pujante, porém mais sölido, como veremos adiante.

Após a fase eminentemente policultora pela qual passa o município de Taquaritinga, dois novos produtos começam a ganhar expressão e se fazerem cada vez mais presentes na econo mia local: a laranja e a cana.

A primeira cultura mostra um desenvolvimento um pouco anterior. Advinda principalmente da região de Bebedouro, que aparece como o grande centro citrícola dessa região do Estado, a cultura da laranja começa a crescer vigorosamente em Taquaritinga, e em toda a região, a partir da década de 50, e, 
Já em 1959 , o municfpio em questão aparece como o quinto produtor do Estado.

TABELA 5 - Evolução da área plantada e do número de produtores para os principais produtos em Taquaritin ga, SP. 1959 e 1970

\begin{tabular}{|c|c|c|c|c|}
\hline \multirow{2}{*}{ Cultura } & \multicolumn{2}{|c|}{1959} & \multicolumn{2}{|c|}{1970} \\
\hline & No est. & $\begin{array}{c}\text { Área colhida } \\
\text { (ha) }\end{array}$ & N8 est. & $\begin{array}{c}\text { Area colhida } \\
\text { (ha) }\end{array}$ \\
\hline Laranja & 206 & 1.045 & 493 & 3.696 \\
\hline Cana-de-açücar & 13 & 779 & 28 & 2.105 \\
\hline Café & 330 & 2.292 & 267 & 1.266 \\
\hline Algodão & 304 & 2.350 & 27 & 413 \\
\hline Arroz & 499 & 2.184 & 555 & 3.103 \\
\hline Milho & 500 & 3.374 & 589 & 4.802 \\
\hline Feijão & 210 & 306 & 96 & 129 \\
\hline Amendoim & 196 & 1.156 & 411 & 3.068 \\
\hline
\end{tabular}

Note-se, pela Tabela 5 , que a laranja mais que triplica a área colhida. Deve-se observar que, por ser uma cultura permanente, a área colhida não espelha muito bem o desenvolvimento da cultura, uma vez que a área com novas plantações não aparece na Tabela. Segundo a mesma fonte da Tabela 5 , a relação entre pés novos de laranja e pés em idade produtiva, e ra 0,31 em 1959 e 0,85 em 1970 。 Ou seja, nesta última data, cerca de $46 \%$ dos laranjais de Taquaritinga não estavam ainda em produção, o que nos faz supor que a área efetivamente ocupa 
da com a cultura é quase o dobro da área colhida.

o Recadastramento do Incra efetuado em 1972 já traz uma área colhida de $5.801,4$ ha, confirmando o que dizfamos a cima.

A cana-de-açúcar tem, ao que tudo indica, seu desenvolvimento acentuado no municipio a partir de 1960 - 0 grande centro canavieiro regional é o municlpio de Sertãozinho, e é a partir daf que essa cultura se alastra, passando por Jaboticabal e atingindo Taquaritinga. Não é essa porém a única frente de expansão da cana-de-açúcar. Os municlpios de Guariba e Pradópolis se convertem também em grandes centros canavieiros já a partir de meados de 40. E nesta última cidade que esta situada uma das maiores usinas de açücar do Brasil, a Usina São Martinho.

Dadas as excelentes oportunidades de desenvolvimento da agroindústria canavieira, que não cabe discutir aqui, essas duas frentes de expansão da cana-de-açücar "varrem" toda a região, no sentido oeste, atingindo Taquaritinga.

Digno de nota é o fato de essa cultura ser produzida em poucas propriedades, ao contrário da laranja, e mesmo do ca fé. Acontece que os estabelecimentos que cultivam a cana são, na grande maioria, de propriedade das usinas - ou dos usineiros - das regiöes canavieiras por excelência. Assim é que, somente a Açucareira Corona, cuja usina situa-se no municipio de Guariba, tem nove propriedades no municlpio de Taquaritinga. Isto significa que quase não existe em Taquaritinga a categoria 
de fornecedor de cana. Quem a planta säo os próprios usinelros.

Especialmente nos últinos anos, a cultura da cana-deaçücar instala-se definitivamente em Taquaritinga. Somente a Açucareira Corona, citada acima, possuia $3.203,1$ ha no munici pio, em 1975, contra 442,6 ha em 1967. Somando-se essa ärea de 1975 com as propriedades da Usina Santa Adélia (905,l ha) e da Usina Santa Ernestina (634,0 ha), temos uma área de $4.742,2$ ha mais do que o dobro da área total colhida com a cultura em 1970. (Ver Tabela 5).

Mais recentemente a Cia. Rio Pedrense de Bebidas, pro dutora de aguardente, fez grandes aquisiçães de terras no municlpio (cerca de $2.000 \mathrm{ha}$ ) o que mostra a tendéncia atual da cultura da cana-de-açücar em Taquaritinga.

Mesmo com o extraordinário desenvolvimento dessas cu turas, pode-se observar que a produção de cereais, mais amendoim e algodão, ainda é bastante significativa, ou seja, pelo menos até o momento, o caráter policultor do munfcipio continua.

Essa tendência recente da agricultura Taquaritinguense é espelhada pela distribuição da posse da terra no municlpio. Pela anälise da Tabela 6 , podemos primeiramente verificar que a posse da terra apresenta-se menos concentrada no município de Taquaritinga, sendo um reflexo do desenvolvimento da agricultura regional que, após a decadência do café, transforma-se em pó licultura, sem que um outro produto agrícola apareça como dominante durante longos anos. 0 municlpio de Sertãozinho é inte- 
ressante para a comparação, já que o vácuo resultante do declí nio do café foi rápida e intensamente ocupado pela monocultura da cana-de-açúcar, levando a uma reaglutinação das proprieda des rurais, conforme atestam os índices de concentração, bem mais elevados que os de Taquaritinga e região.

TABELA 6 - Indices de concentração da posse da terra em Tá quaritinga e região, comparados à outros locais

\begin{tabular}{lcccc}
\hline & \multicolumn{2}{c}{1960} & \multicolumn{2}{c}{1970} \\
\hline & $G_{1}(a)$ & $G_{2}(b)$ & $G_{1}$ & $G_{2}$ \\
\hline Taquaritinga & 0,587 & 0,592 & 0,584 & 0,590 \\
Microregião $-G_{12}$ & 0,689 & 0,691 & 0,657 & 0,661 \\
Sertãozinho $(c)$ & 0,782 & 0,787 & 0,779 & 0,782 \\
São Paulo $(d)$ & 0,793 & 0,796 & 0,778 & 0,782 \\
Brasil $(d)$ & 0,841 & 0,843 & 0,842 & 0,844 \\
\hline
\end{tabular}

FONTE dos dados primários: IBGE

(a) Iimite inferior do indice de Gini de acordo com Gastwirth

(b) limite superior do indice de Gini de acordo com Gastwirth

(c) extraido de GEBARA (1976)

(d) extraido de HOFFMANN E GRAZIANO DA SILVA (1975) 
Durante a década de 60 , a distribuição da posse da terra mostra certa estabilidade no municipio em estudo. A paI tir de fins de 60 , porém, é possivel que haja uma tendência a uma concentração da posse da terra. Para verificar esse fa to, calculamos os Indices de concentração relativos a 1967 e 1975 , que são, respectivamente 0,587 e 0,590 . Esses Indi ces foram calculados a partir dos dados individuais dos imóveis rurais, fornecidos pela Unidade Municipal de Cadastramento do INCRA, agrupando-se os imóveis que apresentavam proprietários com idêntico nome. Isto porque de antemão tínhamos conheci mento que a partir de 1972 estava ocorrendo um grande número de transferência de imóveis, e nem sempre essas transferências envolviam imóveis de áreas contíguas. Somente o Indice decon centração calculado a partir dos proprietários rurais permitiria detectar essas transferências."

Os Indices encontrados não permitem uma conclusão a favor do aumento da concentração da posse da terra.

Entretanto, a entrada maciça das culturas da cana-deaçücar e da laranja dá,sem dúvida, novos rumos à agricultura de Taquaritinga. Segundo levantamentos feitos em fevereiro de 1977 pelo IEA, o nümero de pés novos de laranja é da ordem de 550.000 , enquanto existem 2.500 .000 pés em idade produti -

$(*)$ Us índices para os mesmos anos calculados sobre os imó veis sem fazer-se agrupamento, são respectivamente 0,570 e 0,572 para 1967 e 1975 . 
va. A produção colhida na safra $76 / 77$ é da ordem de 862.500 mil frutos, quase o triplo da produção de 1972 , mostrando o enorme desenvolvimento da cultura.

o café tem também mostrado sinais de uma nova expan são, bem mais modesta, a partir de meados da década de 60. As sim é que, segundo o levantamento acima, Taquaritinga estaria hoje com 1.570 .000 pés de café, dos quais 120.000 são novos.

Merecem também destaque a produção de limão, sempre crescente, e com considerável volume de produção (810.000 ca1 xas), e o cultivo de goiaba para indústria, atualmente cerca de 800 ha, com 210.000 pés, sendo 60.000 novos.

o resultado desse desenvolvimento agrícola mais recente, especialmente a enorme expansão das culturas da laran ja e da cana-de-açúcar, é um novo surto de progresso a nível regional. Toda a economia da região, relativamente estagnada durante pelo menos duas décadas e meia, toma novo vigor. De fato, as cidades adquirem um maior dinamismo, o comércio é retomado, multiplicam-se os empregos, enfim, todos os sintomas de um novo surto de progresso. Sob muitos aspectos, esse desenvolvimento recente mostra-se diferente daquele ocorrido no início do século, com a chegada do café à região.

o setor de mercado interno está muito mais desenvolvido e diferenciado. A consolidação desse setor foi possivel porque seu crescimento se deu autonomamente a partir da ruptura com a economia cafeeira. Forma-se então uma base mais sólida para a economia regional, verificando-se uma urbanização 
e uma industrialização das cidades locais, antigos lugarejos.

o setor de subsistência, ainda bastante presente, mos tra-se com caracterfsticas diferentes. Com o desaparecimento do café, o sistema de colonato aos poucos vai deixando de exis tir. Com o fracionamento da propriedade rural, juntamentecom a ocupação de terras antes incultas, não ocupadas pelo café , esse setor é composto principalmente por pequenos agriculto res 1solados. Seus excedentes destinam-se a mercados mais longinquos, à própria capital do Estado, hoje uma enorme metró pole.

Essa diferenclação da economia, resumida no fortalecimento desses dois setores acima, leva a que o desenvolvimento recente seja mais sölido, não se resumindo somente numa at vidade quase que extrativa, como a anterior. Os produtos que trouxeram esse progresso são industrializados na região. A li gação com o exterior se dá através de seus derivados. Multiplicam-se portanto as oportunidades de emprego no setor secundário. A renda gerada permanece em maior parte na região. Há, contudo, uma semelhança com o passado que chega a encobrir todas essas diferenças: fol somente o aparecimentode um produto agrícola exportável que provocou o rejuvenesci mento da economia. Se no passado a "onda verde" dos cafezais é que emprestava pujança à região, atualmente essa "onda verde" é constituída por canaviais e laranjais.

Todos os anos e anos de produção agrlcola diversificada, de agricultura policultora, não conseguiram fazer com que 
a região sofresse um novo despertar económico. Quem o fez foi a laranja e a cana-de-açúcar.

Esse fato vem revelar aquilo que é por demais conhecido entre aqueles que se preocupam com a agricultura brasilei ra: que a produção de gêneros destinados ao mercado interno não consegue provocar o desenvolvimento da própria agricultura e , consequentemente, de toda a economia a ela vinculada. o obstáculo fundamental é que a remuneração dessas atividades não é suficiente para, de um lado, provocar o desenvolvimento das forças produtivas na agricultura, através da modernização da produção agrícola, e, de outra, gerar uma renda que se distribua aos ramos da economia local. Em sintese, a acumulação de capital na agricultura não se realiza com a intensidade suficiente para promover seu desenvolvimento capitalista. A agricultura não se desenvolve, simplesmente sobrevive.

Essa semelhança com o passado leva-nos de imediato a uma indagação: qual a possibilidade da ocorrência de uma crise, tal como a do café, e o subsequente desmoranamento do edifício do progresso económico atual?

A possibilidade da crise existe. Basta que, por qualquer motivo, o mercado internacional se mostre desfavorá vel por um tempo suficiente, que a crise se esboça. Não há dú vidas, porém, que os mecanismos hoje existentes para sua contornação são muito mais eficientes, encontrando-se na maior par te em poder do Estado. 
Assim é que, desse há muito tempo, o governo, através do Instituto do Açúcar e do Álcool (IAA), mantém um rígí do controle da expansão da produção de açúcar, temendo a superprodução. Vários outros instrumentos de política econômí ca podem ser acionados, e são constantemente utilizados, visando a prevenção, ou pelo menos, a amenização dessas crises.

Em que pese a existēncia de mecanismos controladores mais eficientes, não muda a esséncia do fenómeno. Nossa agri tultura só consegue experimentar surtos de progresso quando se vincula com o mercado externo, quando se produz para exporta ção. 
5 - A EVOLUÇÃO DA AGROINDỨSTRIA NA REgIÃO

Dentre as hortaliças cultivadas em todo o mundo, o tomate é aquela que ocupa o lugar de maior destaque. A pro dução mundial tem aumentado ano após ano, atingindo em 1975 um total de 30,8 milhöes de toneladas. Os principais paises produtores e exportadores de derivados de tomate são a Itália, Portugal, Espanha, Grécia, Egito, Estados Unidos e, na América do Sul, Argentina e Brasil. (IEA, 1975).

Dentre os Estados brasileiros, São Paulo é o maior produtor, com $521.000 \mathrm{t}$. seguido de Pernambuco e Rio de Janeiro, com 99.720 e 66.628 toneladas, respectivamente, no ano de 1975 , segundo os dados do IBGE.

Na Tabela 7 podemos observar a evolução da produ ção de tomate nos Estados de São Paulo e Pernambuco. 
TABELA 7 - Evolução da produção de tomate em São Paulo e Pernambuco

\begin{tabular}{|c|c|c|c|c|c|c|}
\hline \multirow{2}{*}{ Ano } & \multicolumn{3}{|c|}{ São Paulo } & \multicolumn{3}{|c|}{ Pernambuco } \\
\hline & Área & $\begin{array}{c}\text { Produção } \\
(t)\end{array}$ & $\begin{array}{l}\text { 'Rendimento' } \\
\text { (t/ha) }\end{array}$ & Área & $\begin{array}{c}\text { Produção } \\
\text { (t) }\end{array}$ & $\begin{array}{l}\text { Rendimento } \\
\text { (t/ha) }\end{array}$ \\
\hline 1952 & 5.303 & 87.386 & 16,48 & 6.979 & 54.397 & 7,70 \\
\hline 1957 & 7.580 & 157.547 & 20,78 & 10.454 & 85.499 & 8,18 \\
\hline 1962 & 10.311 & 238.320 & 23,11 & 11.041 & 96.952 & 8,78 \\
\hline 1967 & 13,712 & 318.525 & 23,23 & 10.343 & 159.542 & 15,43 \\
\hline 1970 & 17.903 & 371.257 & 19,84 & 6.984 & 99.243 & 14,21 \\
\hline 1974 & 29.400 & 610.400 & 20,76 & 5.550 & 122.100 & 22,00 \\
\hline 1975 & 24.200 & 521.000 & 21,53 & 4.986 & 99.720 & 20,00 \\
\hline
\end{tabular}

FONTE: $\quad$ IBGE

o Estado de São Paulo apresenta um aumento tanto na ärea colhida como na produção, enquanto Pernambuco, que era o Estado que mais plantava tomate, apresenta uma evolução irregular, e, no decorrer dos anos, cada vez mais se defasa de São Paulo, que assume a posição de maior produtor brasileiro, respondendo por 53,6\% da produção nacional no ano de 1975 .

Esses dados de produção referem-se à soma da produção de tomate estaqueado com tomate rasteiro. De fato, esse produto agrícola é cultivado de duas maneiras bastante dife rentes. A produção do tomate estaqueado destina-se basica mente ao consumo "in natura", enquanto o tomate plantado rasteiro, sem suporte de proteção, destina-se à industrialização. Apesar de haver, grosso modo, essa separação no que diz respeito ao destino da produção colnida, esses dois siste 
mas de cultivo apresentam uma série de outras diferenças que os caracterizam bem mais do que a simples destinação da produ ção .

D cultivo do tomate envarado é feito de uma maneira intensiva. Assim, as äreas plantadas são relativamente pequenas, havendo uma utilização muito grande de trabalho e capital na cultura. A medida que a planta se desenvolve, ela deve ser convenientemente desbastada e tutorada por armações especiais. levando a um uso constante de trabalho na fase de crescimento da cultura. A planta é cuidadosamente tratadacom fertilizantes e pesticidas, uma vez que os frutos devem ser de qualidade a melhor possivel. pois são destinadas quase que exclusivamente ao consumo "in natura".

Já o tomate rasteiro é cultivado extensivamente em grandes áreas. A dotação de trabalho e capital é bem menor se comparada ao outro sistema de cultivo. As áreas destinadas à cultura, depois de devidamente preparadas, são semeadas, e o crescimento da cultura dá-se sem nenhum tutoramento, fi cando as plantas acamadas por sobre o solo, emaranhando-se umas com as outras, daí o nome de rasteiro. Não só a produ ção por área é menor, como os frutos são de qualidade inferior em relação ao tomate estaqueado. Mas a qualidade não importa muito, pois a produção é destinada à industrialização.

- resultado económico dos dois sistemas de plantio pode ser observado na Tabela $B$. Apesar do tomate rasteiro a presentar um custo operacional bastante inferior, tanto o vo- 
lume de produção como os preços obtidos pela mesma são 1gualmente mals balxos, levando a um resultado Ilquido por unidade de ärea desfavorável quando comparedo ao tomate estaqueado.

TABELA 8 - Resultado económico da cultura de tomate, segun do o sistema de plantio - SP. - Safra 1975/76

\begin{tabular}{|c|c|c|c|c|}
\hline Cultura & $\begin{array}{c}\text { Rendimento } \\
\text { (t/ha) }\end{array}$ & $\begin{array}{l}\text { Receita } \\
\text { bruta } \\
\text { (Cr\$/ha) }\end{array}$ & $\begin{array}{l}\text { Custo ope- } \\
\text { racional } \\
\text { (Cr\$/ha) }\end{array}$ & $\begin{array}{l}\text { Recelta } \\
\text { lfquida } \\
\text { (Cr\$/ha) }\end{array}$ \\
\hline Tomate raste1ro & 14.1 & $8.460,00$ & $7.221,96$ & $1.238,03$ \\
\hline Tomate envarado (1) & $41,6^{(2)}$ & $103.920,00$ & $63.364,49$ & $40.555,51$ \\
\hline
\end{tabular}

FONTE: IEA - Prognóstico 76/77

(1) Varledade Santa Cruz

(2) Considerando-se $24 \mathrm{~kg} / \mathrm{calxa}$.

No Estado de São Paulo, a evolução da produção de tó mate envarado e rasteiro pode ser visualizada na Tabela 9.

Como se pode observar, o volume processado é quase sempre malor que a produção de tomate rastelro, o que reflete - fato de que uma parte do tomate envarado é destinada às Indústrias. Na realidade acontece o seguinte: no tomate envarado, as últimas colheitas, por serem de qualidade inferior e, portanto, de diffcll colocação no mercado, são destinadas às Indústrias. Já com o tomate rastelro, ocorre o inverso: os primeiros frutos, de razoävel qualidade, são destinados ao mer cado "In natura", onde conseguem bons preços. As demais co- 
Iheitas dificilmente são aceitas no mercado para mesa, sendo destinados totalmente à Industrialização.

TABELA 9 - Produçāo e industrialização do tomate, São Paulo - 1968/75 (1.000 toneladas)

\begin{tabular}{llllll}
\hline Ano & $\begin{array}{c}\text { Produção } \\
\text { total } \\
\text { Estado }\end{array}$ & $\begin{array}{l}\text { Produção } \\
\text { cultura } \\
\text { envarada } \\
\text { envadução }\end{array}$ & $\begin{array}{l}\text { Proltura } \\
\text { rasteira } \\
\text { ralume } \\
\text { processa } \\
\text { do }\end{array}$ & $\begin{array}{c}\text { Volume comer- } \\
\text { cializado } \\
\text { CEAGESP }\end{array}$ \\
\hline 1968 & 419 & 275 & 144 & 170 & 181 \\
1969 & 381 & 223 & 198 & 180 & 171 \\
1970 & 440 & 286 & 154 & 210 & 224 \\
1971 & 478 & 268 & 210 & 225 & 225 \\
1972 & 488 & 322 & 166 & 190 & 225 \\
1973 & 526 & 392 & 134 & 170 & 251 \\
1974 & 610 & 330 & 280 & 340 & 249 \\
1975 & 706 & 406 & 300 & 340 & - \\
\hline
\end{tabular}

FONTE: Prognóstico 75/76

(1) Estimativa preliminar

(2) Estimativa feita posteriormente ao levantamento de abril

A temperatura é o fator climático mals importante na cultura do tomate, que prefere temperaturas amenas, sendo a 1 deal entre $18 \cdot 26^{\circ} \mathrm{C}$. Esse fator é o principal determinante da época de produção da cultura.

Em Taquaritinga e regiōes vizinhas, a melhor época de semeadura è entre março e abril. Março é preferido porser - mês mais chuvoso. A colheita inicia-se quatro meses após o plantio, prologando-se por dois a trés meses, uma vez que a 
maturação dos frutos ocorre por etapas.

A cultura não é exigente em solos, preferindo os solos leves, podzolizados ou arenosos, que apresentam a vantagem de permitir um maior desenvolvimento do sistema radicular do tomatelro, além de contribulrem para uma menor porcentagem de podridão dos frutos que ficam em contacto com o solo.

No que diz respeito às variedades cultivadas, na nos sa região de estudo a variedade Santa cruz é a mais intensiva mente cultivada, apesar de existirem variedades especificas pa ra o plantio rasteiro, como o ROMA V.F. Acontece porém que além dessas variedades mais especificas serem mals exigentes. principalmente no que diz respeito à irrigação, elas não apresentam boa aceitação no mercado "In natura", devido ao tamanho pequeno e forma irregular, principalmente.

Esse fato leva a que os agricultores prefiram a va riedade Santa Cruz,uma vez que esta lhes permite a destinação de parte da produção para o mercado "In natura", o que geral mente lhes traz malores compensações financelras, visto o melhor preço conseguido. Como veramos, esse é um ponto impor tante no relacionamento entre as fäbricas e os agricultores,jả que às primeiras não é interessante que os segundos desviem par te da produção para o mercado, privando-as dessa produção. Por outro lado, tendo a opção do mercado para consumo "In natura". os produtores diminuem sua dependéncia da indústria processado ra. 
Ainda com respeito à cultura do tomate, resta dizer que essá espécie é multo sugcetivel ao ataque de pragas, e prin cipalmente, doenças de dificil controle. Entre essas últimas, as causadas por vírus e bactérias são as mals comprometedoras para a cultura. A prática agrícola mais recomendável e eficiente para a prevenção das doenças que atacam o tomateiro - da dos os atuais niveis de desenvolvimento tecnológico - é a rota ção de culturas, não se recomendando o plantio nas mesmas áreas anteriormente cultivadas.

o surgimento do tomate na região em estudo está muito mais ligado ao municipio de Monte Alto que ao de Taquaritinga. Com efeito, é em Monte Alto que encontramos os primeiros indicios da existência da cultura de tomate. Ao que tudo indica. já na década de 20 o tomate era cultivado com certa intensidade no Municipio, e quem o cultivava eram os colonos, meeiros, parceiros e pequenos proprietários em geral, que formavam o setor de subsistência tão importante e necessário à economia cafeeira. As áreas de cultivo eram localizadas nos lugares hoje conheci dos como Barreiro e Agua Limpa. Esses locals, devido princi palmente ao solo, de características hidromórficas, ou seja, so los não totalmente constitufdos, localizados na encosta do chapadão da Serra de Jaboticabal, foram deixados de lado pelo café e possivelmente destinados aos colonos e demals categorias do setor de subsistêncla, que nesses locals praticavam sua agri cultura independente. 
Esses pequenas produtores cultivavam verdadeiras hor tas em suas restritas posses, e nessas hortas o tomate era um produto que se sobressaía aos demais. Talvez a origem ita liana dos produtores explique o cultivo do tomate nessa época. o fato importante é que o tomate era produzido pela população ocupada na economia exportadora dominante. Em outras pala vras, dedicar-se ao plantio do tomate era pobre quem o fazla. Tanto é que os fazendeiros de café sentiam-se ofendidos com a atribuição de plantadores de tomats.

A produção de tomate assumia, para seus produtores. ao mesmo tempo valor de uso e de troca. Parte da produção era processada pelas unidades familiares e constituía elemento de sua subsistência. o tomate era cozido em tachos àé "dar - ponto" - a massa de tomate - e armazenado em grandes recipientes, geralmente de vidro, para ser consumido durante o decorrer do ano. Enquanto tal, o tomate era valor de uso. Mas, ao mesmo tempo,parte da produção - a que excedia o consumo de subsistência - era vendida a intermediários, que agrupavam es sa produção, e a destinavam para o processamento industrial em Jundial. 0 transporte era feito em cestas e por via ferroviá ria. Nessa época existia a estrada de ferro Cia. Melhoramentos de Monte Alto, com extensão de $29 \mathrm{~km}$, ligando Vista Alegre ao distrito de Ibitirama, por onde passava o ramal "bitola estreita" da Cia. Paulista. A venda do tomate trazia certa ren da em moeda aos produtores, e enquanto tal, tinha valor de tró ca para os mesmos, ou, assumia o caráter de mercadoria. 
Em Jundial, a "CICA" era a responsável pelo processamento do tomate, distribuindo seus derivados principalmente na capital do Estado. cujo mercado Interno encontrava-se em ex pansão.

Advinda a crise de 1929, a produçäo de subsistência da região sofre um incremento, uma vez que a atividade exporta dora quase que cessa, e o tomate começa a aparecer com maior vulto. Dado que o escoamento da produção era relativamente fäc1l, Inclusive com a "CICA" Incentivando esse fornecimento de matérla-prima, já que tinha que atender a um mercado cres cente nos aglomeramentos urbanos que se constituiam, até os grandes produtores experimentaram o plantio da cultura,que nes sa ëpoca parecia compensador.

Fruto desse incremento de produção, surgla por volta de 1931 a primeira fábrica local de processamento do tomate: a "Zamora" , pertencente à família dos Hernandes. Quase que na mesma época, outras duas fábricas semelhantes se constituem no município. Com isso, os excedentes que eram enviados para Jundiaf começaram a ser absorvidos na própria região, diminuIndo sobremaneira o fluxo da matéria-prima para fora.

Essas fábricas eram bastante rudimentares, apenas um passo além da indústria familiar. Verdadelros barracões, reu niam um volume malor de matéria-prima que era cozida em seus vários fornos, sendo a massa de tomate posteriormente embalada em vasos ou barricas, e destinados à capital, já que a indústria doméstica ainda se faziz bastante presente, inexistin- 
do mercado interno local.

Por volta de 1936 , é montada em Monte Alto a prime ra indústria alienfgena ao local. Tratava-se da Castro Ribe任 ro Agroindustrial S. A. (CRAI), de propriedade do Comendador do mesmo nome, oriunda da capital. Os então responsáveis pela administração püblica municipal deram total apoio à iniciativa, resultando na instalação de uma enorme fábrica na cidade. Pouco tempo depois, já no fím da década de 30 , a "CICA" e a "PEIXE" também se instalavam no municipio.

A Instalação dessas três fábricas representa, por um lado, um novo incentivo à produçäo de tomate, e, por outro lado. determina a derrocada das pequenas fábricas locals. Estas, pressionadas pelo grande capital industrial, fecham suas portas. E o processo de centralização do capital, no qual os pequenos sempre levam desvantagem, sendo arruinados em prove1to do grande capital.

o cultivo do tomate espalha-se por toda a região a partir da fixação dessas fábricas em Monte Alto, e cada vez mals modificam-se as condições em que é realizado. Ao lado das minúsculas àreas ocupadas com a cultura começam a apare cer plantações cada vez maiores - se bem que reduzidas em com paração às áreas plantadas atualmente. A mão-de-obra ocupada na cultura, antigamente estritamente familiar, é cada vez mais constituida por assalariados, especialmente por ocasião da coIheita; que se torna mais volumosa em função dos . maiores plan tios. 
Assiste-se à desintegração da indústria doméstica de processamento de tomate. Este val cada vez mais adquirindo valor-de-troca, transformando-se em mercadoria. E, mais do que isso. a produção simples de mercadorias, em que cada produ彑 tor possui e opera seus próprios meios de produção, val sendo substituida pela producão capitalista, na qual a propriedade dos melos de produção é de uns e o trabalho é executado por ou tros.

Dentre essas modificaçōes, há de se dar destaque a um aspecto importante: a existência de intermediários. A mu dança do local de destino da mercadoria que agrupavam leva a que os mesmos assumam uma nova função. Antes, apesar deles serem responsáveis pela entrega do tomate nas fábricas processadoras, o meio de transporte utilizado era a ferrovia, quer dizer, a propriedade do meio de transporte não lhes cabia. Agora, o tomate deve ser entregue nas indústrias em seus pró prios meios de transporte - o carro-de-boi e, mais recentemen te o ceminhão. Essa nova responsabilidade limita a possibi lidade de qualquer pessoa vir a tornar-se intermediário. só pode sè-lo quem tem meio de transporte.

Ds intermediários recebiam da indústria uma comissão em dinheiro pela entrega da mercadoria, além do "carreto" do transporte. Firmavam contrato com as fábricas para a entrega de uma quantidade estabelecida, e, na época da safra, saím a coletar o tomate dos produtores, que, para não terem sua colheita preterida, tratavam muito bem o intermediário. Tanto 
que estes últimos eram pessoas respeitadissimas na região. Notere que esses intermediários do tomate eram um tanto diferentes dos intermediários que de um modo geral exis tem na agricultura brasileira. Essa diferença reside no fato de que o intermediária de um modo geral é quem fixa o preço dos produtos que compra, sendo o responsável pelo pagamento da mercadoria. Em suma, é ele quem compra a mercadoria. Já no caso do tomate não. Aos intermediários cabe a função de entregar a mercadoria na indústria, sendo est o quem fixa o preço e efetua o pagamento ao produtor.

A Tabela 10 mostra a área colhida e a produção de tomate em vários municípios do Estado de São Paulo, em 1955.

TABELA 10 - Área colhida e produção de tomate no ano de 1955 em vários municipios - SP.

\begin{tabular}{lrc}
\hline Municipio & Area colhida (ha) & Produção (t) \\
\hline Monte Alto & 1.936 & 13.068 \\
Talaçú & 250 & 2.625 \\
Taquaritinga & 220 & 2.250 \\
Santa Adélia & 121 & 1.750 \\
Fernando Prestes & 150 & 1.500 \\
Taiuva & 120 & 255 \\
\hline
\end{tabular}

FONTE: Lavoura em São Paulo. Estatistica Geral e Agrícola dos Municipios do Estado de S. Paulo.

Nessa época, o município de Monte Alto era não só o centro processador do tomate como também o grande produtor re 
gional. Um outro produto era também extremamente importante para a economia de Monte Álta nessa época. Tratava-se do ma mão, fruta bastante cultivada no municipio, a que inclusive tem uma origem semelhante à do tomate. Assim, em 1957, o ma mão era o produto que aparecia em primeiro lugar em valor de produção agrícola de Monte Alto, com Cr\$54.000.000,00, seguido do tomate, com Cr\$30.000.000,00 e do café com ........ $\operatorname{Cr} \$ 20.710 .000,00$, segundo o IBGE (1958).

Entretanto, nesse ano de 1957 , o produção de tomate já é inferior à de 1955 , mostrando os primeiros indicios de sua decadẽncia no municipio. Ao mesmo tempo, bem próximo de Monte Alto, um outro local começa a ter sua produção acres dida rapidamente, e que se tornaria dentro de poucos anos, a capital nacional do tomate: trata-se do municipio de Taquar tinga.

A evolução do tomate nesses dois municipios durante a década de 50 pode ser visualizada na Tabela 11.

TABELA 11 - Produção de tomate, em toneladas, nos municipios de Monte Alto e Taquaritinga - década de 50

\begin{tabular}{lcc}
\hline Anos & Monte Alto & Taquaritinga \\
\hline 1950 & 2.433 & 304 \\
1955 & 13.068 & 2.250 \\
1959 & 10.362 & 6.249 \\
\hline
\end{tabular}

FONTE : IEGE 
A Inexistência de dados mais precisos torna impossí vel perceber-se a partir de que ano Taquaritinga suplanta Mon te Alto em termos de produção. Porém, segundo informações ou tras, logo no início da década de 60 o primeiro assume a lide rança na produção de tomate nessa região.

Ao que tudo indica, a pouca disponibilidade de terras em Monte Alto, devido principalmente à existéncia da cultu ra do mamão, levou a que a cultura do tomate se deslocasse para a localidade vizinha. Deve-se também considerar que o municipio de Monte Alto é relativamente pequeno em termos de extensão territorial, apresentando. segundo o Censo de 1970, uma área total de 28.643 ha. Para comparação, esse mesmo dado é de 53.554 ha para Taquaritinga. Aconteceu que, à medida que a cultura do tomate se expandia, la ocupando áreas que, a partir de um determinado momento, extrapolaram os limites da demarcação politica de Monte Alto, adentrando nas áreas perten centes a Taquaritinga.

Em que pese a passagem de Taquaritinga à condição de maior produtor de tomate, a indústria processadora continuava em Monte Alto, inexistindo em Taquaritinga fábrica de grande porte que processasse o produto. Havia a Agro-Industrial Amá lia S.A., do grupo Matarazzo, fábrica de doces em geral e que fazia massa de tomate. Mas Monte Alto continuava como o centro de industrialização do produto.

No ano de 1966 , a "PAOLETTI" adquiriu por meio de compra a "AMÁIA". Era o início da industrialização em larga 
escala no municipio. De uma capacidade máxima de moagem de 6 t/hora, a "PAOLETTI" ampliou as antigas instalações para 20 t/ hora. No ano seguinte a "PEIXE" instala-se também em Taquaritinga, encerrando suas atividades em Monte Alto e substituin do sua antiga fábrica por outra muito melhor aparelhada e de maiores dimensões. Nesse mesmo ano, a "CICA" ampliava suas instalaçōes e, devido ao fechamento da "CRAI", tornava-se a única fábrica processadora em Monte Alto.

A instalaçäo das unidades industriais em Taquaritinga trouxe enorme estímulo à produção de tomate no municipio. Pela Tabela 12 . percebemos que a produção referente a 1968 é quase o dobro se comparada à de 1967.

TABELA 12 - Evolução da produção de tomate no município de Taquaritinga - SP.

\begin{tabular}{lrll}
\hline Anos & Produção $(t)$ & Anos & Produção $(t)$ \\
\hline 1950 & 304 & 1970 & 50.000 \\
1955 & 2.250 & 1971 & 22.000 \\
1959 & 6.249 & 1972 & 22.000 \\
1965 & 10.000 & 1973 & 20.000 \\
1966 & 21.200 & 1974 & 22.000 \\
1967 & 27.000 & 1975 & 22.500 \\
1968 & 48.000 & 1976 & 10.328 \\
1969 & 40.000 & & \\
\hline
\end{tabular}

FONTE: IBGE para os anos de 1950 e 1959 ; Estatistica Geral e Agricola dos municipios do Estado de São Paulo para 1955 : levantamento próprio para 1976 ; IEA para os demais anos. 
Taquaritinga entra em sua fase eufórica no que diz res peito ao tomate. O jornal "A Cidade de Taquaritinga", em sua edição de $11 / 07 / 67$, noticiava o fato de que um deputado havia solicitado a criação, no município, de uma estação experimental com direção de um engenheiro agrōnomo especializado em hortaliças,"... considerando possuir o municíplo o galardão honroso de maior produtor de tomate do mundo por área cultivada, quer para consumo, quer para industrialização". o tomate era nessa época quem emprestava brilho ao municipio. Realizaram-se "Festas do Tomate" e outras comemorações próprias à situações como essa, co muns em vários outros locais do Brasil.

Recorde-se que nessa época a cultura da laranja mostra va-se já bastante desenvolvida - Taquaritinga era, em 1970, o sétimo produtor estadual - e, conforme já mostramos, estava em franca ascensão na região. A laranja era porém ofuscada pelo tomate.

Não durou muito a euforia. Já em l97l declina consideravelmente a produção local, levando a que se escrevesse que "Esta (a produção de tomate), em virtude de fatores que desconhe cemos, vem se apagando paulatinamente, e aquele posto que ostentamos de 'Capital do Tomate', vai deixando de ter a sua razão". (Cidade de Taquaritinga, 24/07/71) .

A produção de tomate estabiliza-se ao redor de 20.000 toneladas. 0 nümero de produtores declina, porém, de ano para ano. Pelo Senso Agropecuário de 1970 havia 310 estabelecimen tos que se dedicavam à cultura, enquanto que o Recadastramento 
de 1972 registra apenas 171 imóveis com cultura de tomate; embora parte da diferença seja certamente devida à diferença entre os conceitos de estabelecimento agropecuário e imóvel rural, tudo Indica que houve uma diminulção no número de produtores de tomate de Taquaritinga. Quando à área ocupada, esta era de aproximadamente 4.000 ha em 1968, no auge da cultura, caindo para 1.840 ha em $1972^{*}$.

A Tabela 13 mostra a produção de tomate na região em 1972. Taquaritinga ainda é de longe o malor centro produtor, respondendo por quase metade da produção regional, apresentando

TABELA 13 - Produção total de tomate na Microregião Homogènea 612 - Serra de Jaboticabal - 1972

\begin{tabular}{lrrrr}
\hline Municipio & $\begin{array}{r}\text { Número de } \\
\text { produtores }\end{array}$ & Área (ha) & $\begin{array}{c}\text { Quantidade } \\
\text { colhida }(t)\end{array}$ & $\begin{array}{c}\text { Rendimento } \\
\text { (t/ha) }\end{array}$ \\
\hline Taquaritinga & 171 & $1.839,9$ & 20.185 & 11,0 \\
Taiuva & 81 & 733,2 & 5.805 & 7,9 \\
Jaboticabal & 45 & 598,3 & 5.275 & 8,8 \\
Talaçu & 80 & 523,5 & 3.668 & 7,0 \\
Pitangueiras & 20 & 262,9 & 2.858 & 10,9 \\
Fernando Prestes & 80 & 372,7 & 2.331 & 6,3 \\
Monte Alto & 108 & 449,0 & 2.073 & 4,6 \\
Vista Alegre do Alto & 68 & 347,2 & 1.917 & 5,5 \\
Pirangi & 102 & 372,4 & 1.748 & 4,7 \\
Bebedouro & 10 & 144,1 & 934 & 6,5 \\
Santa Ernestina & 6 & 55,5 & 302 & 5,4 \\
\hline \multicolumn{1}{c}{ Total } & 847 & $5.698,7$ & 47.096 & 8,3 \\
\hline
\end{tabular}

FONTE: INCRA

(*) Os dados são do IBGE (1972), INCRA (1972) e IEA (1968) 
tambe̊m a mals alta produtividade. E Impostante observar que a ärea média ocupada com tomate por produtor é bastante superior em Taquaritinga $(10,8 \mathrm{ha})$ se comparada com Monte Alto $(4,2$ ha). De um mode geral, isso reflete o fato de que o cultivo do tomate, ao deslacar-se deste üItimo municipio para o primeiro, assume caracteristicas diferentes. A produtividade por área também espelha essa transformação.

A estratificação dos produtores de tomate em Taquaritinga pode ser observada na Tabela 14 . Essa tabela mostra bem que o tomate é mals cultivado nas médias propriedades, diferentemente do que acontecida na época do inicio da cultura na região, quando o tomate era um produto típico de pequenas proprie dades.

TABELA 14 - Produção de tomate em Taquaritinga, SP, por estrato de área total - 1972

\begin{tabular}{rrrcrc}
$\begin{array}{c}\text { Estratos } \\
\text { (ha) }\end{array}$ & $\begin{array}{c}\text { Ni imóveis } \\
\text { c/tomate }\end{array}$ & Área média & $\begin{array}{c}\text { Quantidade } \\
(t)\end{array}$ & $\begin{array}{c}\text { Rendimento } \\
\text { (t/ha) }\end{array}$ \\
\hline $0-5$ & 3 & 0,97 & 13 & 4,5 \\
$5-10$ & 4 & 3,0 & 114 & 9,5 \\
$10-25$ & 30 & 3,2 & 616 & 6,4 \\
$25-50$ & 48 & 6,3 & 1.515 & 5,0 \\
$50-100$ & 50 & 11,3 & 6.813 & 12,1 \\
$100-200$ & 19 & 20,6 & 5.300 & 13,5 \\
$200-500$ & 16 & 27,8 & 5.714 & 12,8 \\
mais de 500 & 1 & 24,2 & 100 & 4,1 \\
\hline Total & 171 & 10,8 & 20.185 & 11,0 \\
\hline
\end{tabular}


86.

Resta-nos, nesse 1tem, após essa colocação geral da evolução da agroindüstría na região, amarrar essa evolução com - desenvolvimento histōrico da agricultura regional como um todo, buscando outros parâmetros que nos ajudem a explicar mais globalmente o fenómeno da expansão da agroindústría do tomate.

Se reportarmos à época da decadência do café, percebe mos que a região permanece um longo período com a agricultura relativamente estagnada, praticando uma agricultura diversifica da. Contribuía para isso a liberação de terras anteriormente ocupadas com o café, na medida em que este la sendo erradicado. Porém, mais importante do que essa liberação de terras. era o fato de terem permanecido incultas grandes extensões de terras não desbravadas, seja com o café ou com o algodão, multas vezes porque sua fertilidade era inferior. As terras incultas, mantidas como pastagens naturais, eram ocupadas com a pecuária e com os animais de tração ocupados na agricultura. Em suma, a fronteira agricola das áreas agricultáveis não deve ter-se expandido muito, e, quando isso acontecia, as matas eram derrubadas e em seu lugar formavam-se pastagens naturais.

Fol exatamente essa disponibilidade de terras, princl palmente na forma de pastos naturais, que permitiu o desenvolvi mento da cultura do tomate. Na verdade, a cultura do tomate a parece como grande desbravadora das áreas não ocupadas com cultü ras. Devido ao fato do impedimento do plantio do tomate na mesma área por anos consecutivos, por causa do ataque de doenças, sucessivamente novas áreas eram destinadas ao seu plantio, 
enquanto que as anteriormente utilizadas eram ocupadas com outras culturas. Esse fenómeno pode ser visualizado na Tabela 15.

TABELA 15 - Utilização das terras em Taquaritinga, SP. 1950,1960 e 1970

\begin{tabular}{|c|c|c|c|}
\hline Ocupação & 1950 & $\begin{array}{c}\text { rea Cha } \\
1960\end{array}$ & 1970 \\
\hline Culturas permanentes & 5.550 & 4.540 & 9.978 \\
\hline Culturas temporárias & 13.388 & 13.095 & 16.281 \\
\hline Pastos naturais & 39.163 & 18.069 & 1.981 \\
\hline Pastos artificiais & 2.062 & 11.900 & 16.025 \\
\hline Matas naturais & 1.747 & 3.210 & 1.911 \\
\hline Matas plantadas & 1.335 & 1.430 & 628 \\
\hline Terras Incultas & 3.662 & 1.413 & 4.366 \\
\hline
\end{tabular}

FONTE: IBGE - Censos Agrícolas.

0 ano de 1950 deve ser comparado com cuidado aos dema1s, já que o municipio de Taquaritinga foi desmembrado nessa década. Entre 1960 e 1970 , entretanto, os dados são homogè neos, permitindo a comparação imediata. o que vemos é a área de culturas aumentando. principalmente a referente às culturas permanentes, enquanto cal drasticamente a área ocupada com pastos naturais. 0 Recadastramento do INCRA de 1972 já nos traz uma área de $13.342,1$ ha ocupada com culturas permanentes, e $16.124,9$ ha com culturas temporárias. Sem dưvida, é a cultura de laranja que contribui em malor parte para esse enorme aumento da área das culturas permanentes no municipio. 
88.

A nível regional, é necessário termos em conta que por volta de 1950 o municfpio de Bebedouro já se encontrava bastante ocupado com a cultura da laranja, enquanto que a cana-de-açúcar era dominante nos municipios de Sertãozinho, Guariba e Pradópo11s. Entre essas localidades situam-se Monte Alto e Taquaritinga, configurando um certo vácuo que veio a ser ocupado com a cul tura do tomate, entre outras. A Serra de Jaboticabal pode ser Imaginada como um limite geográfico e fisico-que envolve também uma mudança no padrão de solo - que demorou a ser transposto pela expansão agrícola, principalmente canavieira, que teve seu centro em Ribeirão Preto. 
89.

\section{6 - A AGROINDOSTRIA DO TOMATE hOJE}

A produçăo de tomate em Taquaritinga, e em toda a região, sofreu um açentuado declinio no ano de 1976. 0 ataque, particularmente forte nesta ültima safra, da doença "Requeima do Tomateiro". causada pelo patögeno Phitophthora infestans, ocasionou grandes perdas na produção da olerícola. A perda média por produtor fol segundo nossos dados, ao redor de $48 \%$, havendo entretanto produtores que perderam a quase totalidade da cul tura ao lado de outros com perdas bem pequenas. Essa diferença deveu-se, principalmente, à época de plantio da cultura, ten do menores perdas quem realizou o plantio mais tardio.

Alguns paràmetros, como a área plantada e o nümero de produtores, mostram-nos que a cultura do tomate encontra-se declinante no município, visto que o nümero de produtores em 1976 
foi de 71 , plantando uma área de 806,3 ha de tomate, mostrando uma redução de $58,5 \%$ e $52,6 \%$ respectivamente, se comparados aos dados do ano de 1972 : Como a produção total caiu menos do que isso $(48,8 \%)$, pode-se concluir que entre 1972 e 1976 houve um aumento na área média com tomate por produtor e na produtividade por área do mesmo, apesar do ataque da doença neste último a no.

Esse aumento na área média e também na produtividade por hectare deve ser atribuido à participaçäo dos arrendatários na produção de tomate. Pela Tabela 16 , observamos que a área média com tomate dos arrendatários é duas vezes maior do que a de proprietários ou parceiros. Em termos de produtividade, es ta fol de 13,8 t/ha para os primeiros contra 10,8 t/ha para os proprietários.

TABELA 16 - Nümero de produtores e área plantada com tomate segundo a condição do produtor. Taquaritinga,SP. 1976

\begin{tabular}{lccccc}
\hline & Proprietários & Arrendatários & Parceiros & Total \\
\hline N9 produtores & 53 & 13 & 5 & 71 \\
Area total (ha) & 484,0 & 267,6 & 52,1 & 803,5 \\
Area média & 9,1 & 20,6 & 10,4 & 11,3 \\
\hline
\end{tabular}

FONTE: Questionário

(*) Os dados de 1972 săo do INCRA e os de 1976 são baseados em nossos levantamentos 
Este fenômeno da importância crescente de arrendatá rios na produção de tomate é relativamente recente. Historica mente, sempre existiu essa categoria de produtor, mas nunca com peso importante. Mals recentemente, porém, a importância de arrendatários na cultura de tomate tem sido crescente, por motivos que tentaremos deixar mals claros no decorrer do trabalho.

E preciso ressaltar que, apesar das áreas plantadas com tomate serem pequenas, a área total da propriedade de quem o planta, conforme mostramos na Tabela 14 , é bem superior, ou se ja, de um modo geral, o tomate não é atualmente uma cultura de pequenos proprietários. Multas vezes um grande proprietário cultiva uma pequena extensão de área com tomate, levando-nos à falsa impressão de que o tomate é uma cultura de pequena proprie dade. Baseados nos. dados de nosso levantamento, construimos as Tabelas 17 e 18 que mostram esse fato.

TABELA 17 - Produção de tomate entre os proprietários por estrato de área total. Taquaritinga, SP. - 1976

\begin{tabular}{ccc}
\hline Egtratos (ha) & Ne produtores & Area média com tomate (ha) \\
\hline menos de 10 & 1 & 0,7 \\
$10-25$ & 7 & 5,7 \\
$25-50$ & 9 & 6,6 \\
$50-100$ & 12 & 9,4 \\
$100-200$ & 5 & 12,3 \\
ma1s de 200 & 5 & 16,0 \\
\hline
\end{tabular}


TABELA 18 - Número de produtores de tomate por estrato de área com tomate. Taquaritinga, SP - 1976

\begin{tabular}{rc}
\hline Estratos $($ ha $)$ & $N^{9}$ produtores \\
\hline $0-5$ & 18 \\
$5-10$ & 23 \\
$10-15$ & 19 \\
mais de 15 & 11 \\
\hline
\end{tabular}

As condições do plantio do tomate estão bastante relacionadas com o seu cultivo em pequenas áreas, principalmente pelos proprietários rurais. No momento, e mals do que nunca, o to mate é uma cultura de expansão da fronteira agrícola interna das áreas com culturas. Plantado quase que totalmente em áreas cha madas de "gramão" — pastos em que predomina a grama Batatais a cultura do tomate nada mals é do que uma transição à ocupação dessas áreas com outras culturas, geralmente a laranja. A área com gramão é arada e preparada no início do ano e logo depois plantada com o tomate rasteiro, uma vez que durante essa época do Inverno poucas culturas têm condiçōes de se desenvolverem satisfatoriamente.

Após a colheita do tomate, ou é formado o laranjal, ou então a área é ocupada com culturas temporárias, principalmente - amendoim, milho e arroz. No caso da área destinar-se à laranja, como essa cultura demora de dols a três anos para se desenvolver razoavelmente e "fechar" o pomar, os espaços interca- 
lares são ocupados com culturas temporárias, entre elas o tomate. No ano pesquisado, 35,3\% dos produtores de tomate plantavam-no Intercalado no laranjal em formação. E Interessante ob servar que, dentre os arrendatários, dols deles cultivam o toma te Intercalado com a laranja pelo fato de serem formadores de pomares para os proprietários das terras.

Aqui aparece um primeiro ponto que merece destaque: o fato de os produtores de tomate não serem especializados na pro dução do mesmo, ou seja, o tomate não é a atividade principal de quem o planta, salvo, é Importante, os arrendatärios. A malor parte dos atuals proprietários produtores de tomate tèm a principal atividade agricola centrada na laranja, sejam eles pequenos ou grandes proprietários, como atesta a Tabela 19.

Pode-se dizer que, ao mesmo tempo que o tomate é um dos suportes da implementação da cultura da laranja, já que prọ porciona uma renda em dinhelro que multas vezes ultrapassa o custo de formação do laranjal, seu cultivo é atualmente possibi litado em grande parte pela existêncla da cultura da laranja. o que se percebe é que na cultura do tomate são utilizados melós de produção "a priori" destinados à laranja, especialmente máquinas. Assim é que os pulverizadores utilizados na aplicação de defensivos são aqueles utilizados no laranjal; o trator que trabalha a terra para o tomate é o mesmo que gradela o pomar. Mesmo com Insumos esse fato ocorre, se bem que em menor proporção, pols 52,3\% dos proprietários agricultores fizeram financia mento de custelo para o tomate, com vistas à aquisição de adubos 
e pesticidas, com um valor médio de Cr\$2.590,00/ha de tomate. Para os não proprietários esses mesmos dados são $75 \%$ e...... Cr\$2.550,00, respectivamente。

TABELA 19 - Áreas com outras culturas entre os proprietários produtores de tomate. Taquaritinga, SP. 1976

\begin{tabular}{|c|c|c|}
\hline Cultura & Area (ha) & \% da área total \\
\hline Laranja & $1.310,9$ & 30,9 \\
\hline Pasto & 937,8 & 22,1 \\
\hline Cana & 0,0 & 0,0 \\
\hline Golaba & 141,7 & 3,3 \\
\hline Tomate & $403,9^{(3)}$ & 9,5 \\
\hline Outras culturas temporárias (1) & $1.212,9$ & 28,7 \\
\hline Outras culturas permanentes & 233,3 & 5,5 \\
\hline
\end{tabular}

FONTE: Questionário

(1) Essa área está superestimada, já que foi obtida por diferença, incluindo portanto áreas da sede, estradas, etc.

(2) Café principalmente.

(3) Essa área inclul os proprietários amostrados menos cinco questionários que não dispunham de observações sobre área com outras culturas.

Cerca de $28 \%$ dos atuals produtores de tomate ou não pretendem produzf-lo no práximo ano ou mostram-se indecisos. A maloria dos mesmos apresenta como principal justificativa o fato de não disporem de áreas para o seu plantio, mostrando que quase a totalidade do universo agrícola de Taquaritinga já está tomada com culturas, temporárias ou permanentes, restando multo pouco 
de pastagens naturais a serem "desbravadas" com o tomate, o que, sem dưvida, é uma séria limitação ao desenvolvimento dessa cultú ra no municipio. Sua continuidade é também limitada pela cultu ra da laranja, sendo possível o cultivo intercalar só enquanto os laranjais não estiverem formados. A própria cultura de cereais está sendo esmagada pela monocultura da laranja.

Esses comentários reforçam a idéia expressada anterior mente de que a disponibilidade de terras é um fator importante no desenvolvimento da cultura do tomate na região. Apegar-se entretanto a esse ponto como explicação de declínio da cultura é ficar ao nível do fenômeno, superficial portanto. Torna-se necessário buscar pontos que expliquem o porqué do tomate ser preterido pelos produtores. Realmente, deve existir algum problema com a cultura do tomate que o caracteriza como uma cultura pro duzida com a finalidade de cobrir os custos de uma outra, ou seja, uma linha de exploração suplementar para muitos produtores. o entendimento desses problemas significa atingir-se a essência do fenômeno em questão, aquilo que realmente explica o que nos aparece no mundo real, dos fenômenos portanto. E, não temos dū vida, a essência deve ser buscada no relacionamento entre os pro dutores rurais e a indústria processadora do tomate. 0 aprofun damento nessa problemática permite-nos apreender os fatores que levaram ao declínio da produção de tomate na região.

Atualmente os agricultores que se dedicam ao plantio do tomate firmam um contrato de compra e venda com a indústria, no qual é estabelecida a área a ser plantada, as épocas de plan- 
t10. a qualidade exigida para o processamento, além de outras cláusulas, e o preço a ser pago pelo tomate, bem como a obrigação da Indústria de transportar o produto em tempo tal que ele não se deteriore.

A partir do momento em que as fábricas começaram a usar o sistema do contrato direto com os produtores - desde 1971 - deixa de existir a necessidade dos antigos intermediá rio que coletavam o produto e o entregavam na indústria. Se an teriormente a Indústria controlava indiretamente a produção de sua matéría prima, hoje esse controle é direto. As fábricas têm um corpo de técnicos que diarlamente percorrem os produto res, colhendo Informações sobre o andamento da cultura: se o plantio fol efetuado nas épocas estabelecidas pelo contrato; se a germinação fol boa; se tem havido ataque de doenças; enfim,tó dos os dados necessários para que a indüstria tenha uma perfeita previsão acerca da matéria prima que processará.

Inclusive a assistência técnica é multas vezes dada pela própria indústria, conforme pode ser visto na Tabela 20. Essa assistência dada pelos técnicos da indústria é comparável à prestada pelos vendedores de pesticidas. No fundo, o Inte resse malor não é o agricultor, mas sim o capital que os técnicos servem.

A dependēncia dos produtores rurals manifesta-se em vários aspectos, desde o plantio, com sementes fornecidas pela Indústria, até o pagamento da produção entregue, feita em notas promissórlas a serem resgatadas no prazo de 90 dias $150 \%$ do va- 
lor) e 120 dias ( $50 \%$ restantes). TABELA 20 - Origem da assistência técnica aos produtores
de tomate - Taquaritinga, SP., 1976

\begin{tabular}{lc}
\hline Fontes & Porcentagem \\
\hline Casa da Agricultura & 29 \\
Indústria & 27 \\
Vendedor de Pesticidas & 33 \\
Outras $(1)$ & 36 \\
\hline
\end{tabular}

(1) Principalmente orientaçāo própria

(2) A assistência não é exclusiva

Esse contrato serve mais como garantia para a indústria do que para ser efetivamente cumprido em seus vários itens. Ao inquirirmos os produtores rurais sobre o contrato, os mesmos di ziam que não servia para nada, explicando que quando a safra corria bem e a produção era das melhores, as fábricas não res peitavam as cláusulas contratueis, especialmente aquelas que d $\underline{1}$ ziam respeito ao transporte e recebimento do tomate; quando a safra era rufm. como essa ültima, em que havia falta de matéria prima, as fábricas aceitavam tomate de qualquer qualidade, não fazendo nem classificação do produto recebido, chegando inclusi ve a aumentar o preço estipulado no infcio da safra e constado no contrato.

De qualquer maneira, as caracteristicas do contrato mostram as condições de barganha entre os dols setores envolvi- 
dos. Esse ponto assemelha-se bastante com o sistema de cotas. empregado pelas usinas de açücar com respelto aos fornecedores de cana. E uma maneira de se moldar a produção agrícola de acordo com as necessidades e possibilidades da indústria.

Vários outros aspectos merecem ser destacados para mostrarem não só um conflito de Interesses entre a agricultura e Indístria, ou melhor, entre as classes envolvidas nesse con£1to. mas principalmente a predominãncla do capital industrial sobre o agricola.

Um primeiro aspecto é o ligado ao recebimento e classificação do tomate nas fábricas. Na safra de 1974 houve uma enorme produção, principalmente nas novas regiões de plantio,ca so das regiões Paulista e Noroeste do Estado, produção essa além das expectativas das fábricas, ocasionando uma crise de superprodução. A "PAOLETTI", recém-montada em Araçatuba naquela época, desviou grande parte da produção daquela região para o processamento na fábrica de Taquaritinga, sobrecarregando esta última. 0 que se viu fol a formação de enormes filas de camirihões carregados com tomate, que chegavam a esperar um, dols e até três dias para descarregar o produto. Esses caminhões eram multas vezes fretados pelos produtores e permaneciam horas e horas nas filas, enquanto os caminhões da própria fábrica não respeitavam a fila e descarregavam a mercadoria.

A carga dos caminhões que permaneclam na fila começava a se deteriorar e, devido ao sol, os tomates se desidratavam, perdendo água, e, por conseguinte, perdendo peso. No momento 
em qua a carga era recebida, a fábrica descontava na classificação da mercadoria, que era inferior, além da perda de peso, já que o tomate é pago por tonelada entregue. o produtor safa,por tanto, duplamente lesado.

Não é somente em épocas de crise como essa que existem problemas no recebimento da mercadoria. A queixa dos produto res quanto a esse ponto é constante. Em termos médios, pode-se dizer que o desconto devido à classificação da matéria-prima situa-se entre 15 a $20 \%$. Outro problema, alnda com respelto a es se ponto, embora de difícil comprovação, diz respeito à própria pesagem do tomate. Muitos agricultores reclamam que sua colhe1 ta pesa menos na balança da indústria. Contam-se casos de quem pesou de antemão a carga a ser enviada, e a diferença fol da ordem de $800 \mathrm{~kg}$ em um caminhão de tomate. Verdade ou não, todos os produtores acreditam no caso, mas sentem-se impotentes para fazer algo.

Talvez o principal aspecto no relacionamento entre os produtores de tomate e as indústrias seja a questão do preço da matéria-prima. Mesmo porque, descontos como os efetuados na classificação e recebimento do tomate podem ser encarados como uma diminuição no preço estipulado para a matéría-prima.

A fixação do preço mínimo a ser pago pelo tomate entre gue na Indústria mostra as condiçöes de relacionamento entre os setores. Os representantes da indústria processadora e das ins tıtuições governamentals envolvidas reunem-se com certa antecedêncla e estabelecem o preço da tonelada de tomate. Não há pas 
ticipação direta dos produtores, mesmo porque não existe uma entidade representativa dos tomaticultores. Ora,o preço estabe lecido tende ser multo mals favorável à indústria do que aos pro dutores agricolas.

GUIMARÃES (1976), num estudo sobre o complexo agroin dustrial no Brasil, assim se refere à questão dos preços: "E do Interesse da indústria em geral - e não só dos industrials atuantes no complexo agroindustrial - que os preços agricolas sejam balxos, pols com 1sso, os salários na indústria ficam alivia dos das pressões decorrentes dos altos custos da alimentaçã as sim na medida em que essas pressões ocorrem, os preços agrícolas mals altos causam altas salarials indesejávels para o conjunto da Indústria. No que toca às Indüstrias processadoras, altos preços agrícolas têm dupla inconveniência, primeiro por afetar os nivels dos salários e, segundo, por significarem altas dos preços das suas matérias-primas".

Realmente, o mecanismo de preços è um Importante mecanismo através do qual a Indústria exerce sua influência sobre o setor agrícola. 0 que nos parece fundamental nessa questão ë o grau de competição entre os setores envolvidos. Enquanto o setor Industrial apresenta-se oligopolizado, a produção agrícola é pulver1zada. BARAN e SWEEZY (1974:60-61), analisando o capi talismo monopolista, afirmam que "A pequena empresa se localiza na extremidade receptora, reagindo às pressões das grandes empre sas e em certa medida modelando-as e canalizando-as, mas sem o poder efetivo de contrabalancá-las e ainda menos de exercer uma 
iniciativa independente própria. (...) as empresas menores deveriam ser tratadas como parte do ambiente dentro do qual operam as grandes empresas, e nào como um ator no palco".

E por demais sabido que um mercado oligopolista leva a lucros mals elevados. No caso da indústria processadora de tomate, a posição de oligopólio e oligopsónio leva a uma situação privilegiada frente aos produtores da matéria-prima, uma vez que somente três grandes indüstrias - a "PEIXE" e a "PAOLETTI" em Taquaritinga, e a "CICA", em Monte Alto - são responsáveis pela Industrialização do tomate produzido por um sem número de pro dutores.

De acordo com SWEEZY (1973:305-306) "A ma1s-valia total da sociedade é dividida em numerosos segmentos, cada qual correspondendo em volume à porção do capital social de onde re sulta. E regra geral que a proporção acumulada aumenta com o volume do segmento de mais-valia. Disso se segue que a centra lização em si, reduzindo o número e aumentando o volume dos segmentos, terá o efeito de elevar a taxa de acumulação obtida de um determinado total de mais-valia. 0 monopólio intensifica es se efeito transferindo a mais-valia dos capitalistas menores para os maiores".

Vemos portanto que é ao nível das relações de mercado que parte do excedente gerado no setor agrícola se transfere para o setor não-agrícola, alimentando o processo de acumulação do capital industrial. 
No entanto, é preciso ficar claro que, sob pena de se ver tolhido no fornecimento da matéria-prima, o preço estabelecido deve ser tal que não leve os agricultores à desistēncia da produção .

AMIN (1977:31), coloca que as observações normalmente feitas a respeito da distorção dos preços relativos em detri mento dos preços agrícolas, observações cuja ênfase se coloca ao nível da estrutura de procura ou da estrutura do mercado,ape sar de corretas, são insuficientes para a explicação da submissão da agricultura, dizendo que uma das condições que permite essa submissão "... é a Intervenção do capital dominante no prō prio processo produtivo da agricultura. Este capital não é aquele utilizado na prōpria agricultura sob a forma de equipamen tos avaliáveis na exploração agricola. E o do complexo industrial e comercial alimentar, situado como avalista dos produtores rurais. Este capital impõe ao produtor agrícola um progra ma de trabalho preciso, através da padronização dos produtos,ex tensão da transformação industrial, concentração das redes de coleta e comercialização".

Num apanhado geral, o quadro que temos é o seguinte: estabelece-se um preço pouco compensador aos produtores agrícolas: quando a produção é enviada para a Indústria há descon tos por causa da qualidade da mercadora; já classificada,a mer cadoria sofre uma pesagem não multo flel; por ültimo, do pouco que recebeu pela sua produção, os agricultores recebem o paga mento em notas promissórias descontáveis em 120 dias. Está cla 
ro que este quadro não é dada favorável aos agricultores, è agricultura como um todo.

A única maneira dos produtores de tomate conseguirem um malor lucro com a cultura é destinarem parte da produção para o mercado "In natura", pois os preços são muito mais compensa dores. Neste último aṇo, o preço mínimo estabelecido para o to mate foi de Cr\$0,55/kg, passando logo depois, dada a falta de matéria-prima, para Cr $\$ 0,60 / k g$ de tomate. Nessa mesma safra o preço do tomate - pago ao nível do produtor - vendido para o mercado "in natura", subiu de $\operatorname{Cr} \$ 1,50$ para $\operatorname{Cr} \$ 3,00 / \mathrm{kg}$, do 1nício ao fim da safra.

E certo que os preços estavam anormalmente elevados de vido a que o ataque da doença a que nos referimos fol geral, atingindo também os produtores de tomate envarado em outras regiões do Estado, levando a uma situação de escassez do produto. De qualquer maneira, os preços do tomate para mercado são bem superiores àqueles pagos ao tomate para industrialização, mesmo considerando-se a diferença na qualidade do produto. Aos preços prevalecentes no mercado do ano considerado, era muito mais vantajoso esse canal de comercialização que a industrialização. E fol o que aconteceu. Segundo nossos dados, 38\% da produção de Taquaritinga da safra de 1976 foi destinada ao mercado "in na tura". Nos anos anteriores a destinação média da produção para esse mercado tem sido da ordem de $15 \%$.

O grande comprador da região é o Rio Grande do Sul,que compra tomates no infcio da maturação, verdes ainda, devido à 
distância do destino. Vários outros Estados, inclusive o Pará, também adquiriram em Taquaritinga tomate para mercado. o merca do local fol igualmente grande comprador já que os preços alcan çados no varejo eram tentadores, havendo uma enorme procura por parte de intermediários que desejavam um quinhão do grande negócio que estava sendo o tomate, cujo preço no varejo era Cr\$ 8,00 por kg no infcio da safra, passando para Cr\$14,00/kg logo depois. Apesar do preço pago ao produtor estar sendo compensador, a margem de comercialização era por demais alta, possivelmente muito superior aos custos da comercialização, sobrando ao intermediário um lucro extraordinário dificil de ser justificado.

Não resta dúvida que o produtor conseguiu uma certa renda advinda do tomate. Apesar de ter sua produção perdida em parte, devido à doença, a possibilidade de destinar tomate para - mercado "in natura" compensou a perda. E o tomate é assim mesmo, segundo os produtores. Dá "dor de cabeça" mas nunca dá prejuizo.

Para a Indústría, anos como esse último trazem duplo problema. Além de ter o recebimento da matēria-prima comprometido por causa das perdas na produção, esse recebimento é agrava do com a destinação do produto ao mercado "in natura". E até certo ponto tem que se mostrar complacente, para assegurar a pro dução dos anos vindouros.

Após essas considerações, fica claro o entendimento do caráter da produção de tomate na região. Apesar de ser uma cultura que em geral não dá prejuizos, ela é altamente ins- 
tável quanto a seus resultados, basicamente porque os produtores não têm qualquer amparo na indústria processadora. E nem é de se esperar que tivessem. Ao contrário, eles têm sido constante mente espoliados pelo capital industrial, a não ser em ēpocas que, por uma questão de sobrevivência deste último, as rédeas que os mantêm presos são afrouxadas. Trata-se porém de uma fal sa liberdade, e tão logo as condições se normalizem, o ímpeto ex proprlador do capital industrial é revigorado.

Quando dizemos que a cultura do tomate não dá prejuízos, é necessário ter em vista que a cultura é uma linha de ex ploração suplementar para os produtores, como tentamos salientar no inf́cio desse capitulo. Aliás, é por esse motivo que fica di fícil confirmar se o produtor tem ou não lucro com o tomate. 0 simples cálculo do custo de produção da cultura pouco mostraria, já que a contabilização de alguns custos, principalmente a depre ciação do capital constante, é incluido no custo da laranja. Desse modo, somente a contabilidade total da propriedade mostraria se o produtor tem lucros ou não, e mais ainda, se está acumu lando capital. Mas mesmo assim, seria dificil comprovar a contribuição do tomate na rentabilidade do produtor agrícola.

Essa questão tem interesse quando nos indagamos a respeito de se os produtores de tomate produzem em condições de reprodução simples ou ampliada, ou seja, se há somente uma reposição do capital empregado ou se há efetivamente acumulação de capital. Há alguns aspectos que podem ser considerados no caso. A grande maioria $\{82 \%\}$ dos atuais produtores de tomate dedicam- 
se à cultura hä mais de dez anos. De um modo geral, o índice de mecanização dos produtores é relativamente elevado, com uma média de 1,5 trator por produtor, havendo somente quatro deles que não dispõem de tal máquina. Desses tratores, $64 \%$ podem ser considerados novos, com ano de fabricação entre 1972 e 1976. Com algumas restrições, essa aquisição de novos tratores serve como indicador da ocorréncia de um processo de capitalização. Como porém nosso objetivo principal não é constatar se há acumu lação de capital na agricultura, preferimos deixar a questão em aberto. Importa entretanto salientar que os produtores rurais apresentam uma certa utilização de mäquinas agrícolas,notada não só pelo uso de tratores, como também de outros implementos, como arados, grades e pulverizadores motorizados, mostrando um certo nivel de desenvolvimento capitalista.

Falta-nos ainda discutir um problema importante no relacionamento agricultura-indústria no caso do tomate. Já disse mos anteriormente que o pagamento da matéria-prima pela indústria é feito na base de promissórias, e que isso é um ponto de discór dia por parte dos produtores, que reclamam o pagamento à vista, ou pelo menos em tempo curto e com maiores garantias.

0 argumento usado pela indústria para justificar essa forma de pagamento é o da falta de capital de giro suficiente pa ra pagamentos à vista. Isso mostra a influéncia das condições da produção agrícola sobre o ciclo de reprodução do capital in dustrial. Como o tomate apresenta sua colheita durante um pequeno período do ano, a possibilidade de fabricação de derivados 
de tomate é também restrita a um só período. A indústria não é nada interessante ter o seu capital ocioso durante grande parte do ano. como coloca MARX (1975 :333-334): "Quanto mais curto o período de rotação do capital, quanto mais reduzido os prazos de sua reprodução dentro do ano, tanto mais rapidamente se transfor ma a parte variável do capital adiantado originalmente sob a for ma dinheiro na forma dinheiro do produto-valor (que inclui maisvalial criado pelo trabalhador para substituir esse capital variável; tanto menor, por conseguinte, o tempo pelo qual o capitalista tem de adiantar dinheiro do seu cabedal, tanto menor, re lativamente a dado volume de produção, o capital que adianta, e tanto maior, relativamente, a massa de mais-valia que obtém du rante o ano com dada taxa de mais-valia, pois pode com mais frequéncia e continuadamente readquirir os trabalhadores e pôr seu trabalho em movimento, com a forma dinheiro do valor que eles mes mos produziram".

Além de realizar o pagamento pela matéria-prima 90 e 120 dias após o recebimento, duas fórmulas são utilizadas pela indústria para diminuir o período de reprodução do seu capital: a primeira é o processamento de outros produtos além do tomate e a segunda é a dilatação dos períodos de plantio do tomate.

Quanto ao primeiro ponto, além do tomate, as fábricas processam ainda goiaba, laranja, batata-doce e milho verde,trans formando-os em doces. Dentre esses produtos agrícolas, a goiaba é a mais processada, tendo atualmente um volume considerável. E interessante que a "PAOLETTI" produz grande parte da goiaba 
que industrializa em propriedades próprias. A área total das propriedades do Sr. Francisco Carmelo, presidente da PAOLETTI, é de 247 ha - repartidos em quatro propriedades -, encontrando - se ocupadas em grande parte com goiaba e outros produtos indus trializáveis, exclusive tomate. No entanto, muitos outros proprietários dedicam-se ao cultivo da goiaba, que tem uma área plan tada em Taquaritinga ao redor de 800 ha.

Grande parte dos problemas enfrentados com respeito ao tomate se repetem com a goiaba, com um agravante: essa cultura é permanente, levando à maior dependência dos produtores em rela ção à indústría.

No que diz respeito ao segundo ponto, a indústria esta belece no contrato que firma com os produtores, épocas diversas de plantio, abrangendo desde janeiro até junho, numa tentativa de ampliar o prazo de colheita, ao mesmo tempo que evita problemas de acúmulo de matéria-prima em determinada ëpoca. A possibilidade do plantio tardio, em maio ou junho é dada pela irrigação da cultura. Apesar dos tomaticultores de Taquaritinga não usarem irrigação, as outras recentes regiões produtoras, principalmente a de Novo Horizonte, garantem o fornecimento mais tardio, de tomate irrigado, atendendo às necessidades da indústria. Através desses meios é possível à indústria diminuir o período de rotação do capital empregado, possibilitando uma mais frequente utilização de trabalho, pago com a forma do valor que esse próprio trabalho produziu, diminuindo as necessidades de adiantamento de capital pela indústria e consequentemente, aumen 
tando as possibilidades de lucro, razão da própria existência do capital.

Necessitamos agora mostrar algumas características ligadas aos produtores agrícolas que nos permitam enxergar melhor a origem do excedente econömico transferido para a indústria, e portanto justificar o enquadramento da agroindústria do tomate na terceira forma de extração de exc3dente, discutida a nível teó rico no terceiro capitulo deste trabalho.

As características mais importantes dizem respeito à utilização de mão-de-obra na cultura. A grande exigência de tra balho no tomate ocorre por ocasião da colheita. A planta pro duz os frutos em pencas que vão amadurecendo sucessivamente e que devem ser apanhados num tempo relativamente curto para que não se deteriorem e sofram descontos anormais ao serem entregues para processamento. Como a produção de tomate é contínua, o tempo de colheita estende-se por cerca de dois meses, e até mais, sendo efetuada em intervalos de sete a dez dias. Dado essa característica do tomate, há necessidade de um grande volume de trabalho por ocasião da colheita. Segundo nossos dados, do total de trabalho utilizado na cultura, 75\% o é por oca sião da colheita, $20,5 \%$ em tratos culturais e somente $4,5 \%$ no plantio.

Nos primórdios do desenvolvimento da cultura na região, como os produtores eram pequenos proprietários e não dispunham de condições para contratarem mão-de-obra, a cojheita era realizada em forma de mutirão entre as famílias que se dedicavam ao 
cultivo do tomate. Além do mais, as äreas eram menores e consequientemente, o volume de produção a ser colhido também o era. Mas mesmo nessa época,já se utilizava trabalho assalariado, prin cipalmente por aqueles que plantavam áreas maiores - em torno de 6 a 10 ha. Com o enorme aumento da produção regional, o uso de trabalho assalariado foi ficando comum, tornando-se quase obrigatório aos tomaticultores.

Atualmente, os produtores de tomate de Taquaritinga dis tribuem-se da seguinte maneira quanto à ocupação de mão-de-obra:

- $12,5 \%$ usam somente trabalho familiar;

- $19,6 \%$ não utilizam mão-de-obra faminlir;

- 67,9\% usam mão-de-obra familiar mais permanentes e/ou temporária;

- 41,0\% dos proprietärios tèm empregados permanentes. num total de 99 pessoas.

o aspecto quantitativo é porém mais importante que o tipo de mão-de-obra utilizada. o trabalho familiar representa cerca de $24,4 \%$ do total de trabalho utilizado na cultura do tomate, o restante sendo trabalho assalariado, seja permanente $(2,2 \%)$, seja temporärio $(73,4 \%)$. A utilização do trabalho fä miliar é mais intensa por ocasião do plantio e dos tratos cultu rais, onde representa, respectivamente, 47 e $41 \%$ do total nessas operações. Na colheita representa somente $18 \%$ do total. Essa maior utilização do trabalho familiar no plantio e em tratos culturais é explicada pelo fato dessas operações serem bastante mecanizadas, e a mão-de-obra familiar é utilizada na ope- 
ração das máquinas agrícolas, desde o preparo do solo e plantio até a pulverização de pesticidas, configurando-se portanto como um trabalho qualificado.

O maior volume de mäo-de-obra utilizada, particular mente na colheita, é aquela conhecida como "bóia-fria", tão comum em regiões de agricultura desenvolvida no sentido capitalig ta. Como a colheita deve ser efetuada num tempo curto, contra tam-se turmas de trabalhadores volantes que, em um ou dois dias, fazem o trabalho, deslocando-se em seguida para novo local de colheita. 0 pagamento pelo seu trabalho é feito, quando da co lheita, por caixas de tomate apanhadas, e quando em tratos culturais, por dia de serviço. Em muito pouco diferem dos trabaIhadores volantes empregados nas regiões canavieiras. Talvez a única diferença é que a colheita do tomate exige um trabalho me nos árduo que o corte da cana, levando a que os "bóias-frias" do tomate sejam em grande parte mulheres e jovens. Mesmo porque o infcio da colheita do tomate coincide com a da cana-de-açúcar, concorrendo em mão-de-obra com essa última. Então, à colheita da cana destinam-se aqueles aptos para um trabalho relativamente mais pesado.

Apessr de existirem produtores que não usam trabalho assalariado, ou o fazem eventualmente, o seu número é reduzido, bem como a ärea que cultivam. A regra é a existência de traba Iho assalariado, existindo inclusive uma alta porcentagem de produtores de tomate que tèm trabalhadores permanentes em suas terras, apesar de os utilizarem pouco na cultura do tomate. 
Cremos que as características descritas são suficientes para mostrar que a agricultura do tomate em Taquaritinga se configura como uma produção capitalista. Realmente, a produ ção de tomate é realizada atualmente por médios produtores, em geral pequenos capitalistas agrícolas. Todos os artificios utilizados pelo capital industrial discutidos anteriormente são formas através das quais uma parte do excedente económico gerado na agricultura é transferido para a 1ndústria. Esse exce dente tem como principal gerador o trabalho assalariado necessā rio à reprodução do capital empregado na agricultura. Trata-se, em última instância, de transferéncia de mais-valia da agricultura para a indústría. 


\section{7 - CONCLUSOES}

Na análise que fizemos da agroindüstria do tomate numa regiãa do Estado de São Paulo, percebe-se claramente com o capital Ladustrial vai tornando-se domirante na agricultura à medida que o sistema capitalista se desenvolve. Num primeiro momento dessa investida, o capital industrial destról as bases da indústria doméstica rural, ao mesmo tempo que leva à ruína os pequenos capitais aplicados no mesmo ramo de produção em que se desenvolve o grande capital. Após a consolidação das bases sobre as quais dar-se-ả a acumulação de capital no determinado ramo de produção. o capital dominante parte para a subordina ção das suas fontes de matérlauprima, para a expropriação dos produtores rurais. 
A expropriação dos produtores rurais pode ser total, no sentido de privá-los de qualquer meio de produção a não ser - trabalho, que passará a ser o único meio de sobrevivência dos antigos produtores. Nesse ponto, a dependéncia da agricultura à indústria será total, e o trabalho aplicado na primeira encontra-se subordinado diretamente à segunda.

Há, entretanto, situações em que a expropriação dos pro dutores agrícolas não se realiza totalmente, continuando a existir a detenção dos meios de produção pelos produtores. Isso po rém não impede que os mesmos sejam explorados indiretamente pelo capital. Nessas condições, a subordinação do trabalho ao capital industrial se faz de maneira indireta e parcial. Assim, o trabalho efetuado na agricultura encontra-se subordinado ao cap $\underline{1}$ tal aplicado nesse setor. Mas, desde que esse último luta em condições desiguais e desfavoráveis com o grande capital indus trial, a esse cabe uma parcela do trabalho excedente gerado na agricultura.

A agroindústria do tomate analisada parece-nos encal xar bastante bem nesse último caso. As indústrias processado ras da matéria prima dominam de tal maneira a produção agricola que uma parte do excedente económico gerado na agricultura é transferido para o setor industrial, favorecendo o processo de a cumulação de capital na indústria. Com essa evasão de excedente. os agricultures vêem diminuldas suas possibilidades de acumu lação capitalista. 
E certo que o tomate näo pode ser plantado por duas vezes consecutivas na mesma área. Esse fato, porém, está intí mamente relacionado com o desenvolvimento tecnológico existente para a cultura. 0 desenvolvimento de variedades resistentes às doenças, aliado a um controle mals eficaz das mesmas poderiam eliminar esse inconveniente da cultura do tomate. Mas, esse é o ponto. Esse desenvolvimento tecnológico necessariamente deve ser acompanhado por uma capitalizaçäo mais intensa da agricultura, de uma agricultura efetuada em moldes mais capitalistas. Ora, Isso altera as condições do relacionamento entre o capital industrial e os agricultores, já que esses últimos se fortale cem, prejudicando as possibilidadss de acumulação de capital no polo industrial. Parece ser preferível, partanto, manter a agricultura relativamente atrasada, porque assim as possibilidades de acumulação são maiores.

Há um exemplo que ilustra multo bem essa discussão. Trata-se das sementes utilizadas no plantio do tomate, cuja distribuição é feita pelas indūstrias. Durante o processamento do tomate, as sementes, residuo normal da industrialização, são separadas e secadas convenientemente. Percebe-se que não há qual quer preocupação com o selecionamento das sementes por parte das Indústrias. Esse selecionamento poderia ser feito de várias ma neiras. 0 mals lógico, à primeira vista, seria a indūstria retirar as sementes de culturas por ela mesma conduzida, uma cultú ra que tivesse certa homogeneidade quanto às plantas, além de ou tras características agronômicas que levassem à produção de se- 
mentes selecionadas. Mas não há qualquer interesse em se fazer uma plantação desse tipo. Outro meio de melhorar a qualidade das sementes seria o selecionamento de determinadas culturas, ou parte delas, ou ainda de certos lotes de tomate a ser processa do. de onde se extrairiam as sementes, certamente de melhor qualidade. Mas tal não é feito. O resultado é a distribuição de uma semente altamente heterogénea e de péssima qualidade, que ocasiona grande diminuição na produtividade da cultura, variando conforme o ano, pois às vezes as sementes são razoáveis, já no ano seguinte são péssimas. E não há nenhum controle por parte dos órgãos governamentais a esse respeito.

Sob essas condições de desenvolvimento tecnológico, o tomate é uma planta "migrante" por exceléncia. Na medida em que vão se esgotando os solos virgens onde seu plantio é efetuado, a cultura caminha à procura de novos lugares onde haja terras disponíveis. Nesse caminhar, as fábricas lhes seguem os passos, deslocando-se também. Fato é que, no decorrer de 1974 , a "PAOLETTI" inaugura uma gigantesca unidade industrial em Araçatuba, ao mesmo tempo que a "CICA" instala-se em Presidente Pru dente, Incentivando sobremaneira o plantio de tomate nessas regiões. Segundo o IEA (1975), as DIRAs de Araçatuba, Rio Preto e Presidente Prudente mostraram uma enorme expansão da área cultivada com tomate, que passou de 3.000 ha em 1973 para 11.000 ha em 1974 e 16.000 ha em 1975.

A agroindústria do tomate entra em 1974 em sua nova fa se. Esgotadas em parte as possibilidades de acumulação que por 
vários anos encontrou em Taquaritinga, o capital industrial des loca-se para mais além, onde, provavelmente, sob muitos aspectos o desenvolvimento da agroindústria tomará feições semelhantes. Há, entretanto, diferenças significativas.

o tomate é, nessas regiões, produzido em sua maior par te por arrendatários, algumas vezes, com área superior a 200 ha de cultura, totalmente irrigados e utilizando variedades especificas para industrialização. Esses arrendatários, verdadeiros capitalistas agricolas, ocupam a área por dois anos e depois des locam-se, deixando-a formada quase sempre com pastagens. A indústria aprimora-se, fazendo o transporte da mercadoria em camiIhōes com "piscinas", substituindo o antigo transporte em caixas de madeira.

A agroindústria do tomate nesses novos locais merece por sí só um novo estudo que ultrapassa os limites deste traba 1ho. Nesse novo estudo, a região de Taquaritinga pertencerá ao passado da agroindústria, assim como esse papel coube a Monte A 1 to com relação a Taquaritinga. Mas apesar dessas diferenças,os conflitos entre produtores e indústrias tèm sido bastante seme Ihantes aos estudados. Não cessa a oposição entre os dols setores e, como sempre, a indústria parece estar levando vantagens nesse conflito de interesses.

Num documento que os produtores de tomate dessas regiões enviaram à Secretaria da Agricultura em 1975 denunciando a "dramática situação" em que se encontravam, devido a problemas relacionados com os contratos firmados com a "PAOLETTI", perce - 
be-se claramente que a contradição agricultura-indústria permane ce. Mudou apenas a região onde ela se manifesta.

A conclusão geral a que se chega é de que a agricultura, por ser um suporte da acumulação global do sistema econômi co, deixa de ter uma dinâmica própria, encontrando-se, direta ou Indiretamente, subordinada pelos interesses do capital industrial, Como afirma GUIMARÅES (1976), "Premidas entre duas forças, de um lado pelos que a induzem a consumir insumos em quantidades e variedades cada vez malores, por preços cada vez mais altos, e, de outro lado, pelos que a obrigam a ceder seus produtos a preços mais baixos nem sempre suficientemente compensadores, a agricul tura (...) tende a perder completamente sua capacidade de decisão. ( . . o) à medida que aumenta sua dependência dentro do comple xo agroindustrial. Por conseguinte, o progresso tecnológico. que com a industrializłção se transmite à agricultura, não está proporcionando a esta atividade os beneficios que dele seriam de esperar"。

Ora, a partir dessa perspectiva, torna-se necessário repensar seriamente as polfticas destinadas ao setor agricola. E necessário ter em mente que qualquer modificação proposta à agricultura tem pouca condições de se viabilizar se não estiver em concordância com as determinações gerais do sistema econômi co. Essas determinações refletem, em ültima Instância, as necessidades de domínio econômico, politico e social de uma determinada classe social que detém as rédeas do conjunto da sociedade. 
Conforme BARAN $(1972: 246)$, ".. o destino da agricul tura em um regime capitalista nunca è traçado na agricultura. Os processos económicos, sociais e politicos que se desenvolvem fora da agricultura, especialmente a acumulação de capital e a evolução da classe capitalista (...) passam a constituir, com a consolidação do sistema, os elementos propulsores do desenvolvi mento histórico". 


\section{8 - SUMMARY}

This study focused on relations between Brasil's agri cultural and industrial sectors. More specificaly an analysis was done of relationships between tomato processing industries and tomato producers, in Taquaritinga county, State of São Pau 10

Inicially, the development of capitalist relations of production in agriculture within a peripheric nation-state such as Brazil was discussed. Considering that our objective is to study how a part of the economic surplus which come from agricul tural production is transfered to the non-agricultural sector of the economy, chlefly to the agricultural dependent industries, we have also treated theoretically the economic surplus and the forms in which it is transfered to the industrial sector. 
Theoretical support for our pasition is derived from marxist theory in that it considers surplus to be non-paid labor or surplus labor whose appropriation assumes the form of surplus value in a capitalist society.

We did an historical survey of the agricultural economy of Taquaritinga and the development of its tomato agro-industry. This was followed by a more detalled analysis of existing links between rural producers and processing factories. The lat ter verified that linkages reflect a relationship of dominationsubordination between them.

We perceived that at least part of the agricultural surplus is transferred to the industrial pole when analises are conducted at the level of market relations. Since the industrial pole is an oligopsony and since agricultural production is pulverized, dindustries are able to impose their will on agriculture. The possibilities of extracting a surplus from producers is limited to the extent that if too much is extrac ted formiers will quit producing, and the industry would be limited in its ability to furnish agricultural produce to the mar ket。

A general conclusion reached by the study is that agriculture does not possess internal dynamics since it is merely a support factor for global accumulation of capital within the economic system. To a certain point it is manipulated in accord with needs for reproducing capital for the industrial e conomic sector. 


\section{9 - BIBLIOGRAFIA CITADA}

AMIN, S.. 1977. O Capitalismo e a Renda Fundiária. In: AMIN, S. e VERGopoulos, $K$. A questão Agrãria $\underline{\text { e }}$ 으 Capitalismo. Ed. Paz e Terra. Rio de Janeiro, $799 \mathrm{p}$.

BARAN, P.A., 1972. Economia Politica do Desenvolvimento. Ed. Zahar. Rio de Janeiro. $399 \mathrm{p}$.

BARAN, P. A. e SWEEZY, P。, 1974. Capitalismo Monopolista. Ed. Zahar. Rio de Janeiro, $383 \mathrm{p}$.

BRANT, V.C., 1975. Desenvolvimento Agrícola e Excedentes Populacionais na América Latina (Notas Teöricas). In: Estudos Cebrap 14. pp 101-1lB. Ed. Brasiliense,são Paulo.

D'INCAU e MELO, M. C.. 1975. 므óia-Fria: Acumulação e Miséria. Ed. Vozes. Rio de Janeiro, $154 \mathrm{p}$. 
DUARTE, J。C. e QUEDA, 0., 1974. Agricultura e Acumulação: Algumas Questões in Revista Debate e Critica n8 2 , $p$. 90-97. Ed. Hucitec. São Paulo

HOFFMANN, R。, 1976. Medidas de Concentração de uma Distribuição e a Desigualdade Econômica em uma Sociedade. Série Es tudos $n^{8} 20$, DCSA/ESALQ/USP.

HOFFMANN, R. e GRAZIANO DA SILVA, J。F.. 1975. A Estrutura $\underline{A}$ grária Brasileira. Série Pesquisa $n^{\circledR} 31$. DCSA/ESALQ/USP.

FURTADO, C., 1974. Formação Econômica do Brasilo Cia. Editora Nacional. São Paulo. $248 \mathrm{p}$.

GARCIA, R. C., 1976 . Contribuição para o Estudo do Trabalho Assalariado na Agricultura. Mimeo.

GARCIA, R. C., $1976_{b}$. Formação da Propriedade Especificamente Capitalista da Terra. Mimeo.

GEBARA; J. J., 1976. A Estrutura Agrária no Município de Se $\underline{r}$ tãozinho. Evolução, Caracterização e Efeitos. Dissertação de Mestrado Apresentada a FGV para obtenção do título de Mestre. Mimeo.

GOLDMANN, L., 1967. Cièncias Humanas e Filosofia. Difusão Européia do Livro. São Paulo. $117 \mathrm{p}$.

GUIMARÃES, A. P., 1976. O Complexo Agroindustrial no Brasil. in Jornal Opinião. 5/nov./76.

IANNI, 0, 1976. A Classe Operária Vai ao Campo. Cadernos. CEBRAP $n^{8} 24$. Ed. Brasiliense. São Paulo. 64 P. 
IEA. Instituto de Economia Agricola, 1975. Prognóstico $75 / 76$.

IEA. Instituto de Economia Agricola, 1976. Levantamento Subjetivo de Safras. Não publicado.

IBGE. Instituto Brasileiro de Geografia e Estatistica, 1958. Enciclopédia dos Municfpios Brasileiros.

JUNQUEIRA, A。A. B. et alii, 1972. Aspectos Sócio-Econòmicos da Divisão Regional Agrícola de Ribeirão Preto. Série Estudos $n^{9} 1$. DECOR/FCAV. Jaboticabal, São Paulo.

KAPLAN, A., 1969. A Conduta na Pesquisa. Metodologia para as Cièncias do Comportamento. Ed.Herder. EDUSP. São Paulo. $440 \mathrm{p}$.

KAUSTSKY, K., 1968. A questão Agräria. Ed. Laemmert. R1o de Janeiro. 328 p.

KOSIC, K. 1976. Dialética do Concreto. Ed. Paz e Terra. Rio de Janeiro. $230 \mathrm{p}$.

LoUREIRo, M.R. G., 1977. Parceria e Capitalismo. Ed. Zahar. São Paulo. $135 \mathrm{p}$.

MARTINS, J.S., 1973. Imigração e Crise do Brasil Agrärio. Ed. Pioneira. São Paulo. 222 p.

MARTINS, J.S., 1975. Capitalismo e Tradicionalismo. Ed. Pio neira. São Paulo. $161 \mathrm{p}$.

MARX, K.. 1975a. O Capital. Livro I. O Processo de Produ ção do Capital. Ed. Civilização Brasileira. São Paulo. $933 \mathrm{p}$ 。 


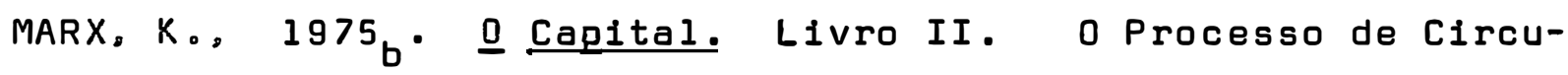
lação do Capital. Ed. Civilização Brasileira. São Paulo. $577 \mathrm{P}$.

OLIVEIRA, F. de, 1974. Crítica a Razão Dualista In Sele čões CEBRAP. n̊ 1. pp.5-78. Ed. Brasiliense. São Paulo.

PRADO Jr.. C., 1969. Contribuição para a Análise da Questão Agrária no Brasil. In A Agricultura Subdesenvolvida.

Ed. Vozes. Rio de Janeiro.

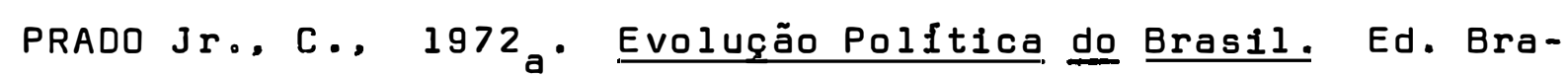
siliense. São Paulo. $250 \mathrm{P}$.

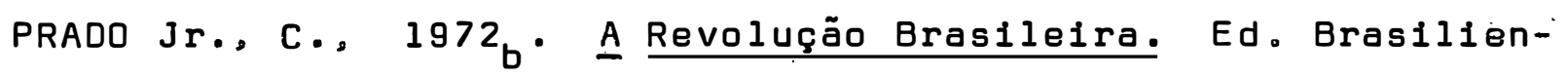
se. São Paulo. $220 \mathrm{P}$.

PRADO Jr., C., 1973. História Econōmica do Brasil. Ed. Brasiliense. São Paulo. $354 \mathrm{P}$.

QUEDA, 0. 1972. A Intervenção do Estado na Agroíndústria Açu careira. Tese de Doutoramento apresentada a ESALQ/USP. Mimeo.

SILVA, S., 1976a. Agricultura e Capitalismo no Brasil. In Revista Contexto n¹. pp. 23-32. Ed.Hucitec。 São Pau 10 .

SILVA, S., $1976_{b}$. Expansão Cafesira e Origens da Industrialização. no Brasil. Ed.Alfa-Omega. São Paulo. 120 p.

SIMONSEN, R.C., 1973. Evolução Industrial do Brasil. e ou tros Estudos. Cia Ed. Nacional. São Paulo. 479 P. 
SINGER, P., 1973. Desenvolvimento e Repartição de Renda no Brasil. In Revista Debate e Critica n n $^{P}$. PP.67-94. Ed. Hucitec. São Paulo.

SINGER, P., 1974. Desenvolvimento Econömico, e Evolução Urbana. Ed. Nacional. São Paulo. $378 \mathrm{p}$.

SWEEZY, Po, 1973. Teoria do Desenvolvimento Capitalista. Ed. Zahar. Rio de Janeiro. $413 \mathrm{p}$.

TAVARES DOS SANTOS, J. V., 1975. A Vivência Camponesa da Insuficiência Econōmico-Social in Debate e Critica n n $^{\mathbf{6}}$. PP.171-176. Ed. Hucitec. São Paulo.

ZAMBONI, S.P., 1976. Aspectos Histöricos-Descritivos do Dis trito de Ibitirama - Monte Alto. SP. Série Pesquisa $n^{8} 5$, DECOR/FCAV. Jaboticabal. São Paulo. 